\title{
Synthesis, Biological Evaluation and Mechanism Studies of C-23 Modified 23-Hydroxybetulinic Acid Derivatives as \\ Anticancer Agents
}

Lixue Lu ${ }^{\text {a, }}$, Hengyuan Zhang ${ }^{\text {a }}$, Jie Liu ${ }^{\text {b, * }}$, Yang Liu ${ }^{\text {a }}$, Yiwei Wang ${ }^{\text {a }}$, Shengtao Xu ${ }^{\text {a }}$, Zheying $\mathrm{Zhu}^{\mathrm{c}}$, Jinyi $\mathrm{Xu}^{\mathrm{a}, *}$

a State Key Laboratory of Natural Medicines and Department of Medicinal Chemistry, China Pharmaceutical University, 24 Tong Jia Xiang, Nanjing 210009, PR China

${ }^{b}$ Department of Organic Chemistry, China Pharmaceutical University, 24 Tong Jia Xiang, Nanjing, 210009, PR China

${ }^{c}$ Division of Molecular Therapeutics \& Formulation, School of Pharmacy, The University of Nottingham, University Park Campus, Nottingham NG7 2RD, UK

*Corresponding authors: E-Mail: jinyixu@china.com; cpu-jill@163.com.

Tel.: +86-25-86185328 (J.Y. Xu)

\begin{abstract}
A series of C-23 modified 23-hydroxybetulinic acid (HBA) derivatives were synthesized and evaluated for their antiproliferative activity against a panel of cancer cell lines (A2780, A375, B16, MCF-7 and HepG2). The biological screening results showed that most of the derivatives exhibited more potent antiproliferative activity than HBA, and compound $\mathbf{6 e}$ exhibited the most potent activity with $\mathrm{IC}_{50}$ values of $2.14 \mu \mathrm{M}, 2.89 \mu \mathrm{M}$, and $3.97 \mu \mathrm{M}$ against A2780, B16, and MCF-7 cells, respectively. Further anticancer mechanism studies revealed that compound 6e induced the generation of intracellular reactive oxygen species (ROS) and reduction of mitochondrial membrane potential (MMP) of B16 cells in a dose-dependent manner.
\end{abstract}


Moreover, western blot analysis indicated that compound $\mathbf{6 e}$ downregulated the expression of anti-apoptotic protein $\mathrm{Bcl}-2$ and upregulated the expression of proapoptotic protein Bax, activation of caspase 3 to induce cell apoptosis. Meanwhile, compound 6e significantly inhibited the phosphorylation of MEK, ERK, and Akt without affecting the expression of MEK, ERK, and Akt. Furthermore, the in vivo anti-tumor activity of $\mathbf{6 e}$ was validated (tumor inhibitory ratio of $68.4 \%$ at the dose of $30 \mathrm{mg} / \mathrm{kg}$ ) in mice with B16 melanoma.

Keywords: 23-hydroxybetulinic acid, structural modification, antiproliferative activity, melanoma, anticancer mechanism

\section{Introduction}

Natural products have been one of the most important sources of leads for the development of drugs for the treatment of cancer [1]. Biologically active polycyclic triterpenoids (generally triterpenoids with dammarane, lanostane, lupane, oleanane and ursane skeletons) are one of the most promising groups of naturally occurring compounds being used as starting molecules in the synthetic transformations [2] for novel drug discovery. Betulinic acid (BA), one of the well-known and well-studied pentacyclic lupane-type triterpenes, has been reported to possess a wide spectrum of biological and pharmacological activities, such as anti-HIV, anti-tumor, and anti-inflammatory, etc [3].

HBA (1), isolated from the root of Pulsatilla chinensis, is considered as hydroxy substituted BA and displays similar anti-tumor activities to BA [4]. Furthermore, HBA exhibited the synergistic cytotoxicity with clinically used drugs such as doxorubicin (DOX) and paclitaxel in vitro and in vivo [5]. In addition, the HBA derivatives could inhibit the activity of a series of ATP-Binding Cassette (ABC) transporters which are known as major factors contributing to multidrug-resistance (MDR) in cancer cells [6, 7]. These results demonstrated that HBA derivatives might be potential therapeutic leads for further research to develop anticancer agents. 


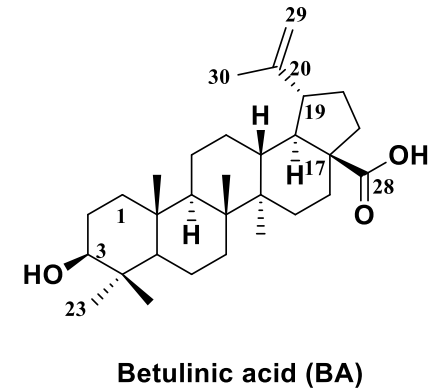

Betulinic acid (BA)

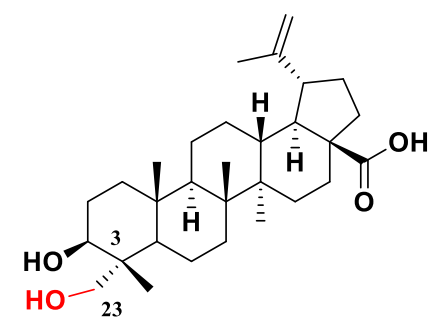

23-Hydroxybetulinic acid (HBA, 1)

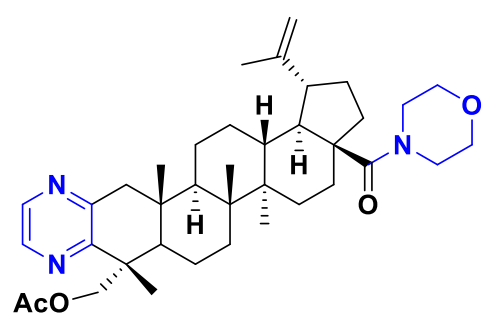

2

Fig. 1. Chemical structures of betulinic acid, 23-hydroxybetulinic acid and compound 2

Previous studies have revealed that HBA exhibited potent apoptotic activity by increasing the formation of intracellular ROS and reducing the MMP of murine melanoma B16 cells [4]. Besides, HBA induced apoptosis of human leukemia HL-60 cells by inhibiting the expression of Bcl-2 and telomerase activity [8]. The results of subcellular localization and uptake profile studies of fluorescent HBA probe suggested that mitochondrion was the main site of probe accumulation in $\mathrm{B} 16 \mathrm{~F} 10$ cells [9]. The mitochondrion-targeted apoptosis in cancer cells along with the low toxicity in normal cells have made HBA derivatives as new promising chemotherapeutic candidates for the intervention of cancers.

Previously, our group has reported a series of C-17 modified HBA ester and amide derivatives $[10,11]$, we also reported a series of heterocyclic ring-fused HBA derivatives, including isoxazole, oxadiazole, pyrazole and pyrazine [12-14]. The promising antiproliferative activity of these derivatives (such as compound 2) prompted us to further design and synthesize novel HBA derivatives. Our previous work mainly focused on the chemical modification of A ring and C-28 position of HBA, less attention was paid to the modification of C-23 position. To improve the anticancer activity of HBA and further supplement its structure-activity relationships (SARs), a series of novel C-23 modified HBA derivatives were designed and synthesized. Herein, we would like to report their synthesis, SARs and anti-tumor activities. In addition, the underlying cytotoxic mechanisms of representative compound $\mathbf{6 e}$ were also elucidated.

\section{Results and discussion}




\subsection{Chemistry}

HBA was isolated from the roots of Pulsatilla chinensis (Bge) Regel [15], and characterized by ${ }^{1} \mathrm{H}$ NMR, ${ }^{13} \mathrm{C}$ NMR and HR-MS. Derivatives 3a-h, 3j-s were synthesized by the reaction of HBA with corresponding acid/amide under condensation condition. Reduction of derivative $\mathbf{3 h}$ afforded compound 3i. (Scheme 1).

As outlined in Scheme 2, HBA was protected with $\mathrm{BnBr}$ in DMF to yield 28-benzyl-23-hydroxybetulinic ester 4. To synthesize derivative 6a, the C-23 hydroxyl group of compound 4 reacted with 4-(bis(2-chloroethyl)amino)benzoic acid firstly, and then debenzylation of compound 4 in THF with $\mathrm{Pd} / \mathrm{C}$ as a catalyst under atmospheric pressure of hydrogen afforded compound 6a. Intermediates 5d-e were obtained using the similar synthetic method for the preparation of $\mathbf{6 a}$, the removal of the protecting group with $\mathrm{CF}_{3} \mathrm{COOH}$ produced the desired derivatives $\mathbf{6 d - e}$. 

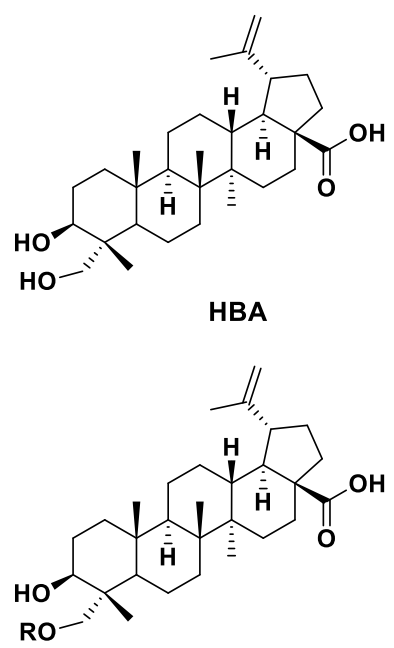

$3 h$
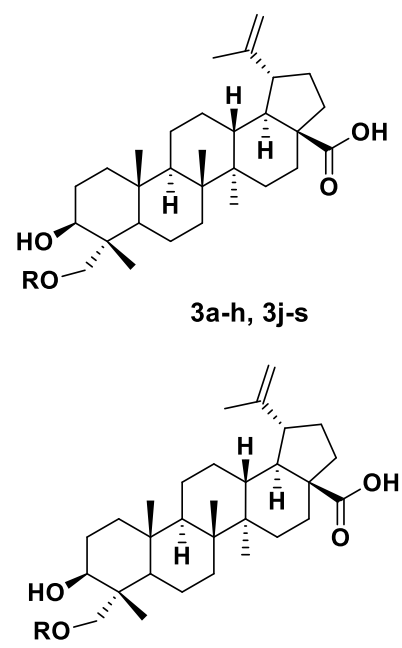

$3 \mathbf{i}$

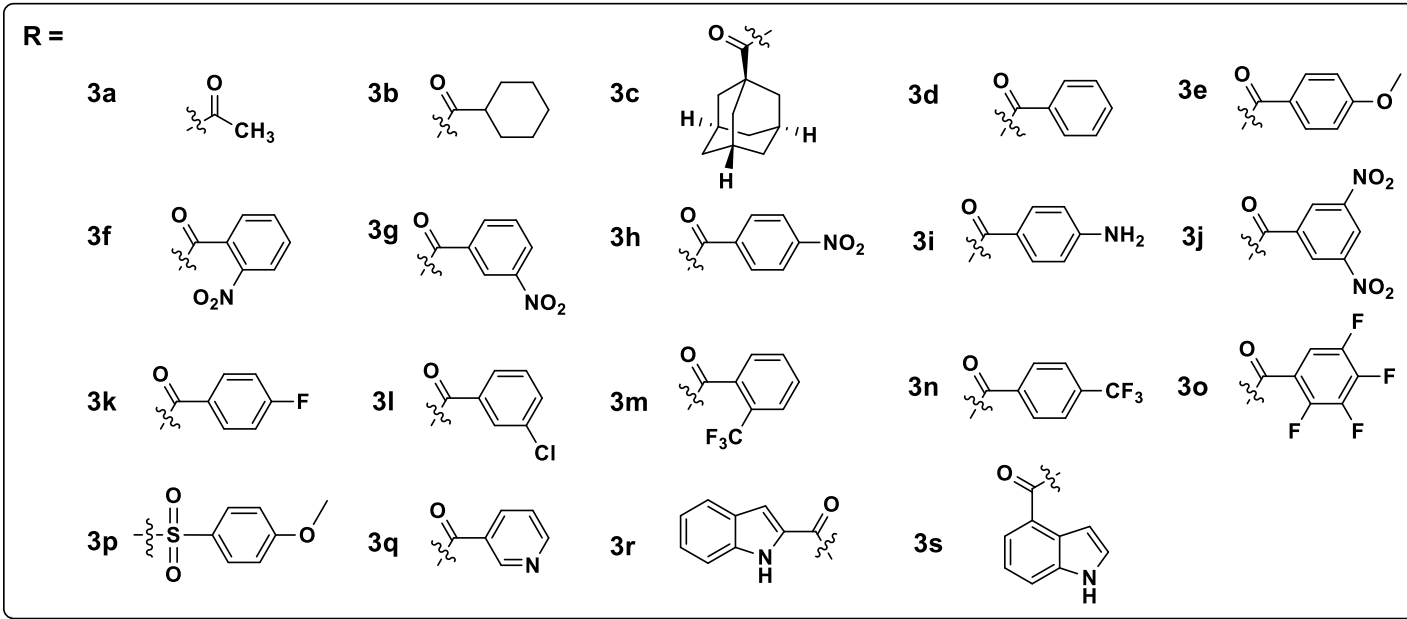

Scheme 1. Synthesis of derivatives 3a-s. Reagents and conditions: (a) Acid/Amide, DCC/EDCI, DMAP, pyridine, rt, 8-24 h; (b) $\mathrm{H}_{2}, 10 \% \mathrm{Pd} / \mathrm{C}$, THF, rt. 

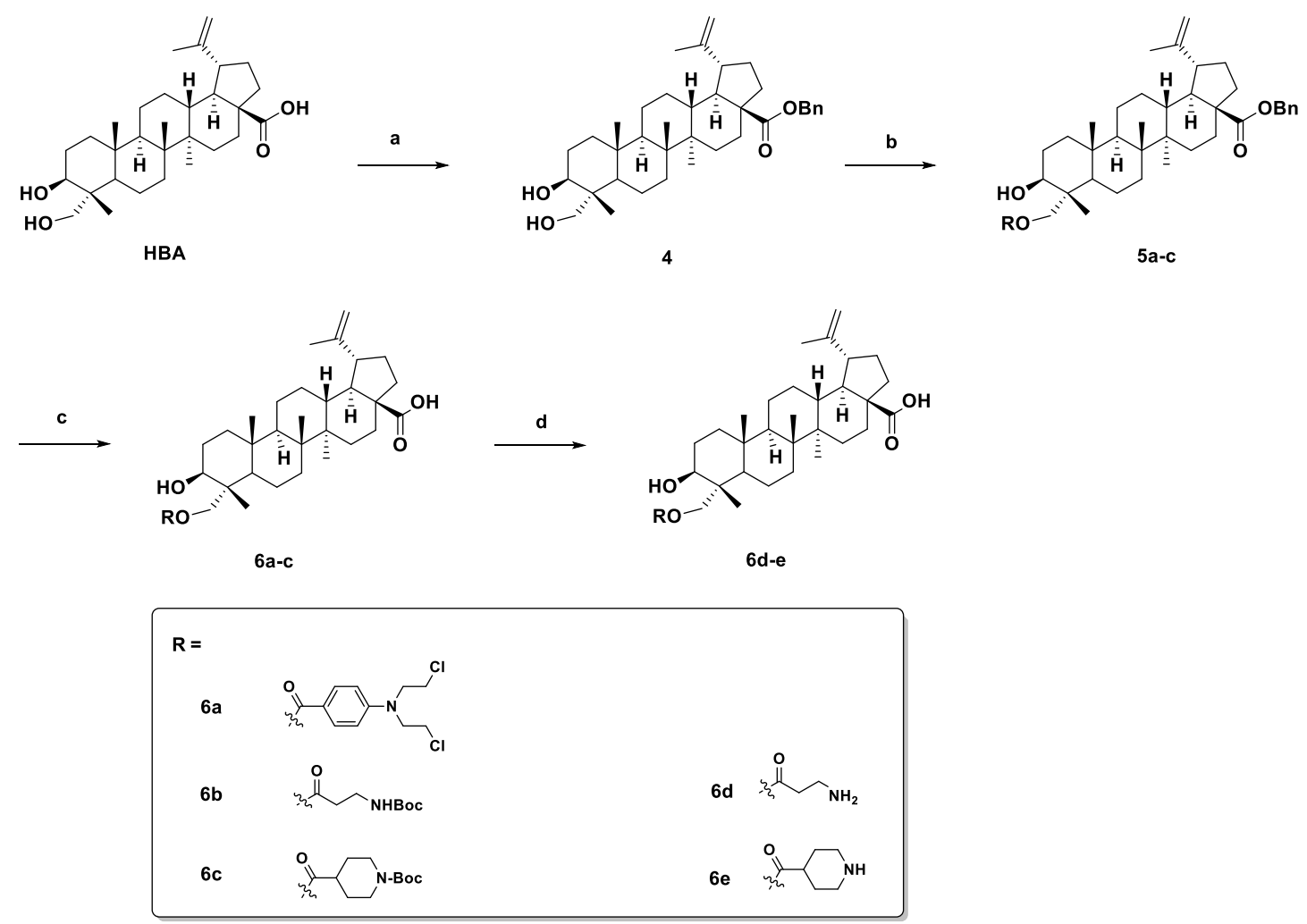

Scheme 2. Synthesis of 6a, and 6d-e. Reagents and conditions: a) $\mathrm{BnBr}, \mathrm{K}_{2} \mathrm{CO}_{3}, \mathrm{DMF}, \mathrm{rt}$; b) protected amino acid, DCC/EDCI, DMAP, pyridine, rt, 8-24 h; c) $\mathrm{H}_{2}, 10 \% \mathrm{Pd} / \mathrm{C}$, THF, rt; d) $\mathrm{CF}_{3} \mathrm{COOH}, \mathrm{CH}_{2} \mathrm{Cl}_{2}, 0{ }^{\circ} \mathrm{C}-\mathrm{rt}, 2 \mathrm{~h}$.

\subsection{Biological evaluation}

\subsubsection{In vitro antiproliferative activity}

In order to analyze the effect of different C-23 substituted groups on the antiproliferative activity, twenty-two compounds 3a-s, 6a, and 6d-e with varying substitution groups were preliminarily screened for their antiproliferative activities in B16 cells by using MTT assay. The results in Fig. 2 suggested that most of the target compounds with substitutions at C-23 position exhibited more potent cytotoxicity at $10 \mu \mathrm{M}$ than HBA. 


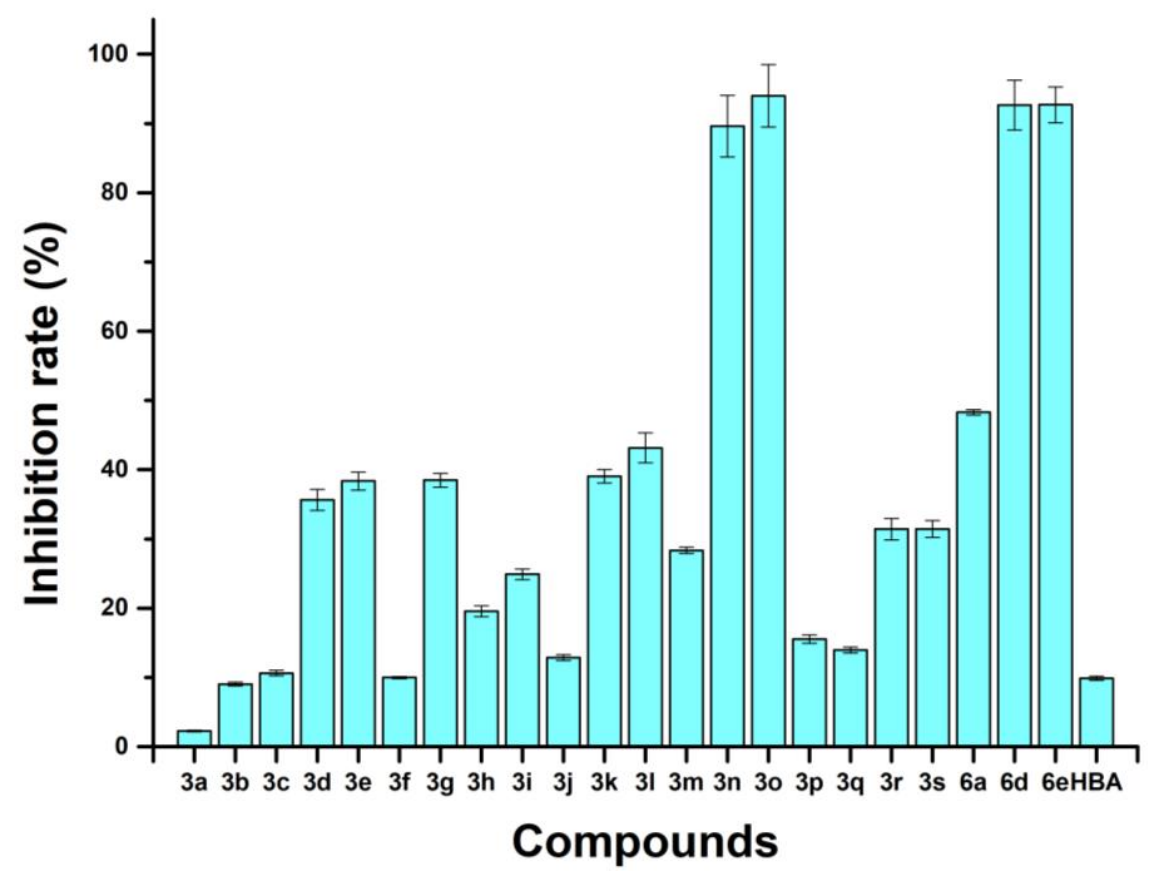

Fig. 2. Histograms display the inhibitory rates of compounds 3a-s, $\mathbf{6 a}$, and $\mathbf{6 d - e}$ against B16 cells.

Based on the above results, we further evaluated the in vitro antiproliferative activities of representative C-23 modified HBA derivatives on five cancer cell lines (A2780 human ovarian cancer, A375 human melanoma, B16 mice melanoma, MCF-7 human breast cancer, and HepG2 human liver cancer cells) and one non-cancer cell lines (L-O2 human normal liver cell line) by MTT assay with doxorubicin as the positive control. The results summarized in Table 1 are presented as the concentration of drug inhibiting $50 \%$ cell growth $\left(\mathrm{IC}_{50}\right)$. 
Table 1. Antiproliferative activities of C-23 modified HBA derivatives against different tumor cell lines and human normal liver cell line.

\begin{tabular}{ccccccc}
\hline \multirow{6}{*}{ Comp. } & \multicolumn{5}{c}{$\mathrm{IC}_{50}$ values $(\mu \mathrm{M})^{a}$} \\
\cline { 2 - 7 } & $\mathrm{A} 2780$ & $\mathrm{~A} 375$ & $\mathrm{~B} 16$ & $\mathrm{MCF}-7$ & HepG2 & L-O2 \\
\hline 3b & $11.31 \pm 2.51$ & $23.73 \pm 1.79$ & $16.70 \pm 1.22$ & $11.40 \pm 0.85$ & $20.28 \pm 1.52$ & $33.27 \pm 1.99$ \\
3d & $19.94 \pm 2.11$ & $15.70 \pm 1.08$ & $17.62 \pm 1.59$ & $18.80 \pm 1.21$ & $12.46 \pm 0.73$ & $26.54 \pm 1.32$ \\
3g & $24.19 \pm 0.89$ & $20.22 \pm 1.45$ & $21.54 \pm 1.68$ & $19.18 \pm 0.99$ & $21.12 \pm 2.58$ & $35.21 \pm 1.43$ \\
3k & $19.78 \pm 1.23$ & $23.73 \pm 3.01$ & $17.21 \pm 1.71$ & $18.75 \pm 0.98$ & $16.24 \pm 1.06$ & $34.15 \pm 1.88$ \\
31 & $7.26 \pm 3.51$ & $13.94 \pm 3.51$ & $10.30 \pm 3.51$ & $9.52 \pm 3.51$ & $10.67 \pm 3.51$ & $21.76 \pm 3.51$ \\
3m & $42.97 \pm 3.52$ & $43.58 \pm 4.31$ & $44.60 \pm 3.61$ & $41.84 \pm 3.87$ & $44.42 \pm 2.65$ & $49.26 \pm 3.66$ \\
3n & $22.61 \pm 3.41$ & $20.40 \pm 1.54$ & $26.96 \pm 3.01$ & $24.84 \pm 2.11$ & $18.71 \pm 1.31$ & $33.61 \pm 1.21$ \\
30 & $12.23 \pm 0.82$ & $13.28 \pm 0.76$ & $7.54 \pm 0.37$ & $5.61 \pm 0.51$ & $13.33 \pm 0.98$ & $21.72 \pm 1.62$ \\
3q & $16.18 \pm 0.99$ & $26.14 \pm 1.72$ & $23.06 \pm 1.82$ & $16.92 \pm 1.33$ & $22.00 \pm 1.98$ & $36.87 \pm 3.92$ \\
6a & $18.50 \pm 1.42$ & $21.50 \pm 2.51$ & $8.49 \pm 0.66$ & $26.83 \pm 1.97$ & $24.34 \pm 2.61$ & $-c$ \\
6d & $2.85 \pm 0.17$ & $5.55 \pm 0.48$ & $3.95 \pm 0.22$ & $3.16 \pm 0.29$ & $2.71 \pm 0.22$ & $11.62 \pm 0.13$ \\
6e & $2.14 \pm 0.08$ & $4.84 \pm 0.32$ & $2.89 \pm 0.11$ & $3.97 \pm 0.16$ & $3.14 \pm 0.22$ & $13.39 \pm 0.43$ \\
HBA & $79.12 \pm 6.50$ & $76.30 \pm 5.31$ & $70.33 \pm 4.71$ & $74.98 \pm 7.38$ & $71.84 \pm 5.56$ & $79.15 \pm 9.01$ \\
ADM ${ }^{b}$ & $0.18 \pm 0.02$ & $0.19 \pm 0.02$ & $0.21 \pm 0.03$ & $0.18 \pm 0.001$ & $0.16 \pm 0.02$ & $0.14 \pm 0.01$ \\
\hline
\end{tabular}

${ }^{a}$ Each data represents mean \pm S.D. from three different experiments performed in triplicate.

${ }^{b} \mathrm{ADM}$ : Doxorubicin.

${ }^{c}$ Not determined.

The data in Table 1 indicated that most of the C-23 modified HBA derivatives exhibited markedly improved antiproliferative activity than HBA, especially against human ovarian cancer cells A2780 and mice melanoma cells B16. Among which, compounds 3b, 3d, 3g, 3k-o, and 3q exhibited more potent activity than HBA, indicating that large steric hindrance substitution at the C-23 position of HBA was more favorable. Moreover, electron-withdrawing substituents and halogens, especially fluorine, on benzene rings at the C-23 position were more favored, as exemplified by 
compounds 3k, 3l, 3n and $\mathbf{3 o}$.

In order to investigate the effect of hydrophilic amino side chains on antiproliferative activity, we designed and synthesized compounds $3 \mathbf{i}, 3 \mathbf{3 r}-\mathbf{s}$, and $\mathbf{6 d - e}$. In which, compounds 6d-e exhibited significantly improved antiproliferative efficacy relative to HBA, and were about 3- to 4-fold more potent than compounds $\mathbf{3 l}$ and $\mathbf{3 o}$, which revealed that the introduction of hydrophilic amino side chains was more beneficial for the activity than the aromatic counterparts. Compound $6 \mathbf{e}$ displayed the most potent activity with $\mathrm{IC}_{50}$ values ranging from $2.14 \mu \mathrm{M}$ to $4.84 \mu \mathrm{M}$ against five cancer cell lines, which is about 30 -fold more potent than the parent compound HBA. Futhermore, $\mathrm{IC}_{50}$ value of compounds $6 \mathbf{e}$ for $\mathrm{L}-\mathrm{O} 2$ cell line is $13.39 \mu \mathrm{M}$, which is $4-5$ fold less potent than those of in cancer cells. Given the potent antiproliferative activity and selectivity of compound $\mathbf{6 e}$, it was finally selected as the candidate for further anticancer mechanism studies.

\subsubsection{Compound 6e induced the generation of intracellular ROS.}

ROS plays an important role in the induction of physiological and pathological apoptosis [16], which are mainly produced in mitochondria. To determine the effects of compound $6 \mathbf{e}$ on ROS generation, the fluorescent probe $2^{\prime}, 7^{\prime}$-dichlorofluorescein diacetate (DCF-DA) was used to evaluate the intracellular ROS levels. As shown in Fig. 3, the ratio of DCF-positive cells was increased from $3.65 \%$ in cells incubated with DMSO to $21.2 \%$ in cells incubated with $3 \mu \mathrm{M}$ of $\mathbf{6 e}$. The result demonstrated that compound $\mathbf{6 e}$ significantly enhanced the intracellular ROS levels in a dose-dependent manner. 


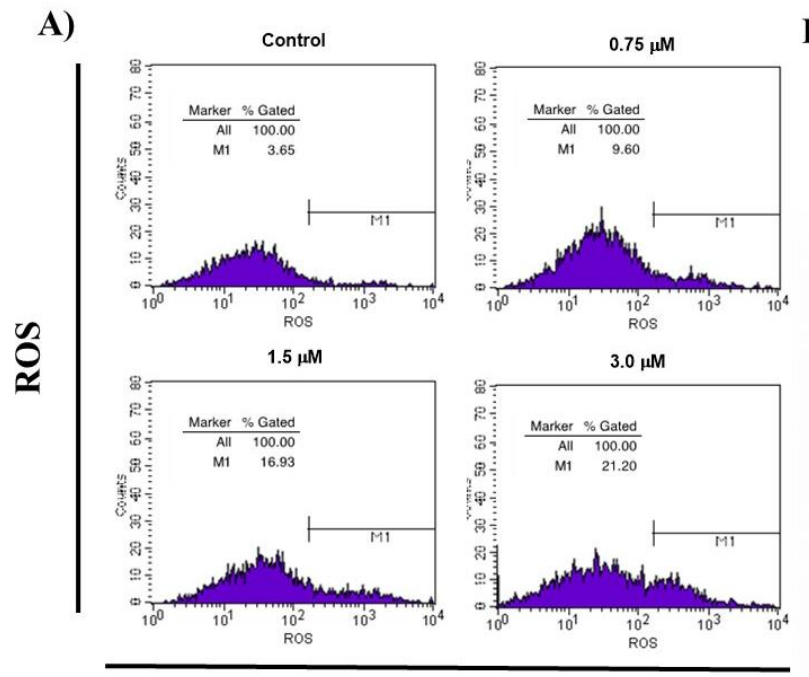

B)

\section{6e B16}

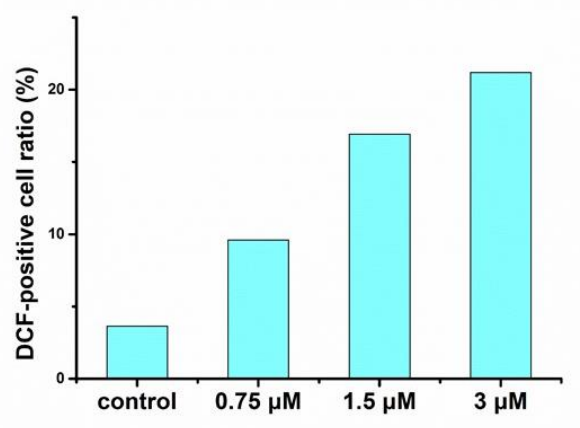

Fig. 3. Effect of 6e on ROS generation in B16 cells. A) Generation of ROS was measured using the ROS-detecting fluorescent dye DCF-DA in combination with FACScan flow cytometry; B) Histogram displays the DCF-positive cell radio in different concentrations $(0,0.75,1.5$ and $3 \mu \mathrm{M})$ of $6 \mathbf{e}$.

\subsubsection{Compound 6e reduced MMP.}

Increasing evidence has indicated that mitochondria plays an important role in regulating cellular functions, which is involved in many pathological processes [17]. Therefore, we further tested the effect of compound $\mathbf{6 e}$ on MMP using fluorescent probe JC-1. As shown in Fig. 4, with the increase of concentrations of $\mathbf{6 e}$ from 0 to 3 $\mu \mathrm{M}$, the green fluorescence intensity (JC-1 monomers, low MMPs) correspondingly increased from 1.57 to $27.05 \%$, which indicated that compound 6e caused MMP collapse in a dose-dependent manner. 
A)

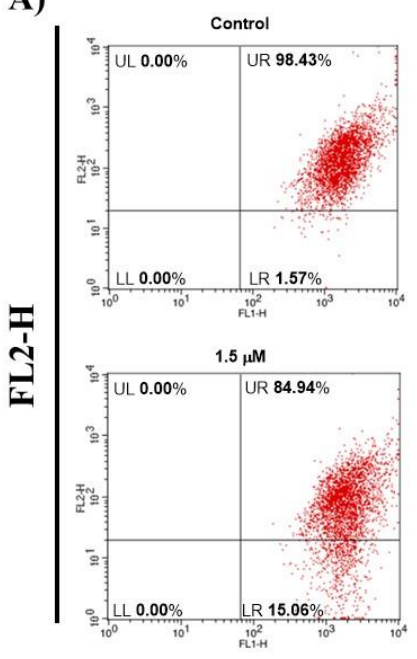

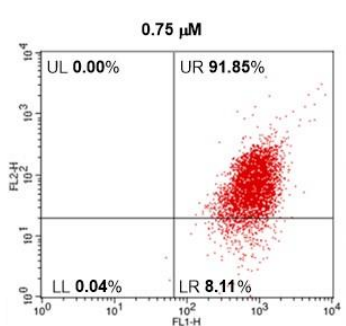

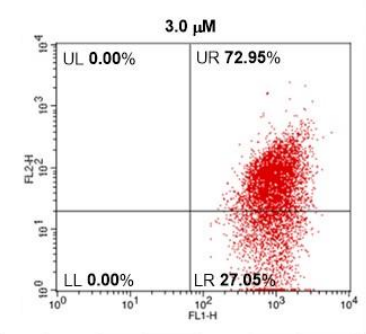

FL1-H
B)

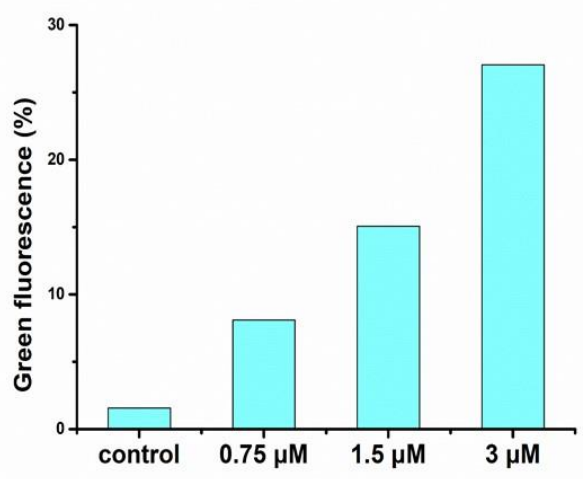

Fig. 4. Effect of $\mathbf{6 e}$ on MMP of B16 cells. A) After incubation with different concentrations $(0$, $0.75,1.5$ and $3 \mu \mathrm{M})$ of $6 \mathbf{e}$ in B16 cells for $48 \mathrm{~h}$ prior to staining with JC-1 dye, the number of cells with collapsed MMPs was determined by flow cytometry analysis; B) Histogram displays the green fluorescence intensity in the absence or presence of $\mathbf{6 e .}$

\subsubsection{Compound 6 e regulated the expression of cell death-related proteins}

\subsubsection{Effects on mitochondrial apoptosis pathway}

To illustrate the potential mechanisms of apoptosis induced by compound $\mathbf{6 e}$, the expression of several apoptosis-related proteins (Bcl-2, Bax, and Caspase 3) in B16 cells were determined by Western blot. As shown in Fig. 5, the expression level of caspase 3 in B16 cells was dramatically increased in a dose-dependent manner after treatment with compound $6 \mathrm{e}(0.75,1.5$ and $3 \mu \mathrm{M})$. Meanwhile, treatments with compound 6e also significantly upregulated the expression of the pro-apoptotic protein Bax and downregulated the expression of the anti-apoptotic protein Bcl-2 in a dose-dependent manner. Collectively, compound 6e triggered mitochondrial apoptosis pathway and induced cell apoptosis. 
A)

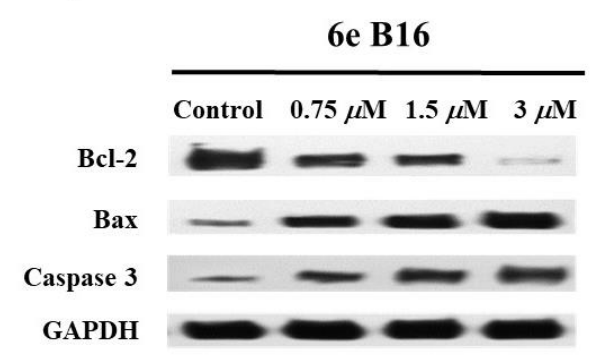

B)

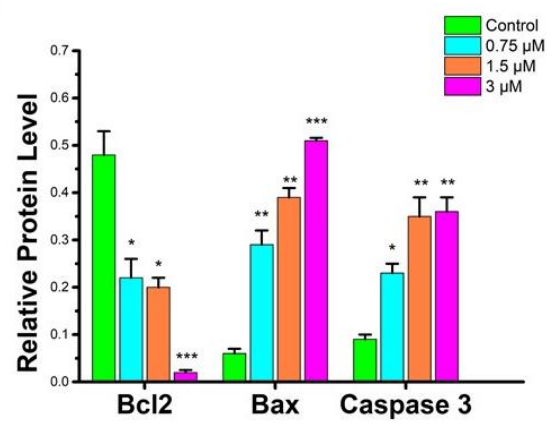

Fig. 5. Effect of compound 6e on the expression levels of Bcl-2, Bax, and Caspase 3. A) Western blot analysis of $\mathbf{6 e}$ on the expression of apoptosis-related proteins in B16 cells treated with different concentrations $(0,0.75,1.5$ and $3 \mu \mathrm{M})$ of $\mathbf{6 e} ; \mathrm{B})$ Histogram displays the density ratios of Bcl-2, Bax, and Caspase 3 to GADPH: $* p<0.05, * * p<0.01$, ***p $<0.001 v s$ vehicle control.

\subsubsection{Effects on signaling pathway MEK/ERK, and PI3K/Akt}

Ras/Raf/MEK/ERK and PI3K/Akt are two important survival signaling pathways in malignant melanoma cells [18], so we further tested the effects of compound $\mathbf{6 e}$ on these two signaling pathways by Western blot in B16 cells. As shown in Fig. 6, compound 6e exhibited significant inhibition on phosphorylation of MEK, ERK and Akt, while had no obvious effects on the expression levels of MEK, ERK and Akt.

A)

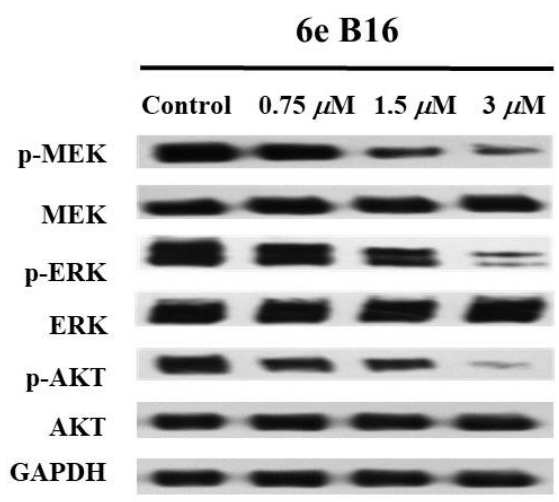

B)

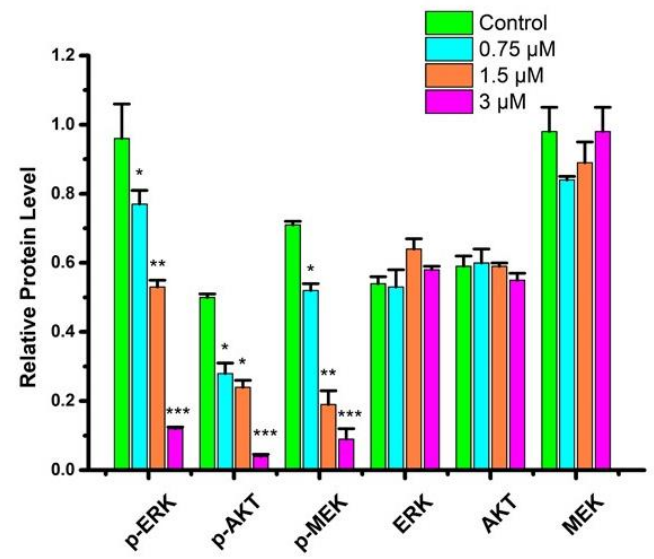

Fig. 6. Effect of compound 6e on the MEK/ERK and PI3K/Akt signaling pathways in B16 cells. A) Western blot analysis of $\mathbf{6 e}$ on the expression of related proteins in B16 cells; B) Quantitative 
analysis showing the levels of each protein relative to control GAPDH: ${ }^{*} p<0.05,{ }^{* *} p<0.01,{ }^{* * *} p$ $<0.001 v s$ vehicle control.

\subsubsection{Compound 6e inhibited the growth of B16 melanoma in mice}

Based on the in vitro results and intensive mechanistic studies, we further tested the anti-tumor activity of compound $\mathbf{6 e}$ in vivo by performing an assay in mice with B16 melanoma. As illustrated in Fig.7, compound 6e significantly and dose-dependently decreased tumor volume and tumor weight. At the dose of 30 $\mathrm{mg} / \mathrm{kg}$, 6e significantly suppressed tumor growth by inhibition ratio of $68.4 \%$, which was somewhat less effective than that of positive control 5-fluorouracil (5-FU, tumor inhibition ratio of $70.9 \%$ ). Meanwhile, 6 e did not obviously affect the body weight at doses of 15 and $30 \mathrm{mg} / \mathrm{kg}$ (Fig.7C). Thus, compound 6e is worthy of further investigation as a potential anti-tumor drug candidate.

A)

1

2

3

4

C)

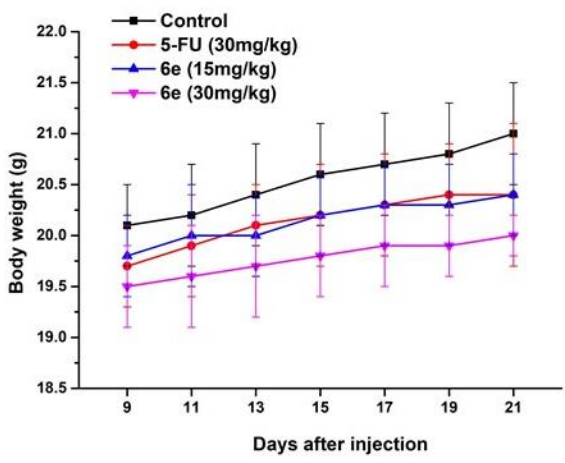

B)

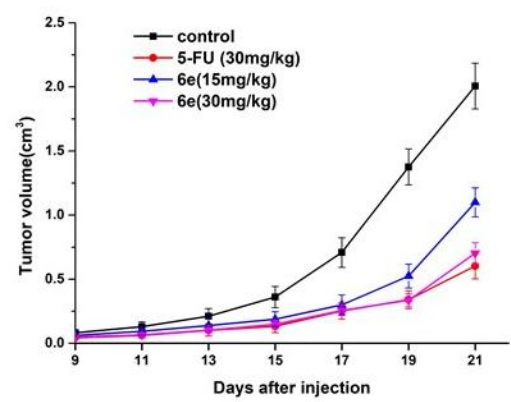

D)

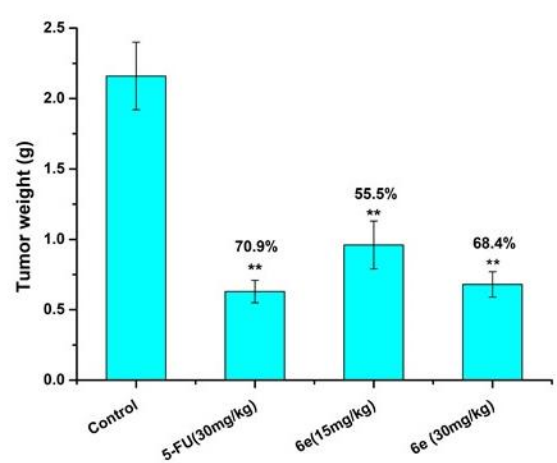

Fig. 7. Compound 6e inhibits B16 melanoma growth in vivo. After administering vehicle (group 1), 5-FU (30 mg/kg per 2 days, group 2), 6e (15 mg/kg per day, group 3), $6 \mathbf{e}$ (30 mg/kg per day, group 4) for 3 weeks, the mice were sacrificed, and the tumors were weighed. (A) Images of tumors from mice at 21 days after initiation of treatment; (B) Tumor volume changes during 
treatment; (C) Body weight changes of mice during treatment; (D) Weight of the excised tumors of each group. $* * \mathrm{P}<0.01$ vs control group.

\section{Conclusion}

In summary, a series of C-23 modified HBA derivatives were synthesized by acylation of the unique C-23 hydroxyl group of HBA. The new synthesized compounds were evaluated for their in vitro antiproliferative activity. The results showed that most of the C-23 modified HBA derivatives exhibited more potent anticancer activity than the parent compound HBA, and the most active compound $\mathbf{6 e}$ displayed the $\mathrm{IC}_{50}$ values at $2.14 \mu \mathrm{M}$ against A2780 cells, $2.89 \mu \mathrm{M}$ against B16 cells and 3.97 $\mu \mathrm{M}$ against MCF-7 cells. Further anticancer mechanism studies revealed that compound 6e induced the generation of intracellular ROS and reduction of MMP in B16 cells. Moreover, western blot analysis indicated that compound 6e downregulated the expression of anti-apoptotic protein $\mathrm{Bcl}-2$, upregulated the expression of pro-apoptotic protein Bax, and activated caspase 3 for causing cell apoptosis. Meanwhile, compound 6e also significantly inhibited the phosphorylation of MEK, ERK, and Akt without affecting the expression of MEK, ERK, and Akt. Furthermore, the in vivo evaluation showed that $\mathbf{6 e}$ exhibited remarkable anti-tumor efficacies against mice bearing B16 melanoma with tumor inhibition rate of $68.4 \%$ at the dose of $30 \mathrm{mg} / \mathrm{kg}$ per day (ip). These results provide a further theoretical insight for the anti-tumor therapeutic application of HBA derivatives. It is expected that the mechanistic and biological studies described, together with our previous reports about HBA derivatives, could expedite the development of new natural product-based therapeutic agents for clinical cancer intervention.

\section{Experimental section}

\subsection{Chemistry}

\subsubsection{General}

Most chemicals and solvents were purchased from commercial sources. Further 
purification and drying by standard methods were employed when necessary. Melting points were determined on an XT-4 micro melting point apparatus and uncorrected. IR spectra were recorded in $\mathrm{CDCl}_{3}$ or $\mathrm{KBr}$ pellets on a Nicolet Impact 410 spectrophotometer. ${ }^{1} \mathrm{H}$ NMR and ${ }^{13} \mathrm{C}$ NMR spectra were recorded with a Bruker AV-300 spectrometer in the indicated solvents (TMS as internal standard): the values of the chemical shifts are expressed in d values (ppm) and the coupling constants $(J)$ in Hz. EI-MS spectra were recorded on an Agilent1100-LC-MSD-Trap/SL spectrometer and High-resolution mass spectra (HRMS) were recorded using an Agilent QTOF 6520.

\subsubsection{3-Hydroxy-23-acetoxy-lup-20(29)-en-28-oic acid (3a)}

To a solution of 1 (100 mg, $0.21 \mathrm{mmol})$ in anhydrous pyridine $(3 \mathrm{~mL})$ was added DMAP $(10 \mathrm{mg}, 0.1 \mathrm{mmol})$ and acetic anhydride $(0.02 \mathrm{~mL}, 0.21 \mathrm{mmol})$. The mixture was stirred for $6 \mathrm{~h}$ at room temperature and then diluted with ethyl acetate $(50 \mathrm{~mL})$, acidified with $1 \mathrm{~N} \mathrm{HCl}(1 \mathrm{~mL})$. Then the solution was washed with water and brine, dried over anhydrous $\mathrm{Na}_{2} \mathrm{SO}_{4}$, and concentrated in vacuo. The residue was purified by chromatography on silica gel (petroleum ether-ethyl acetate 4:1 - 2:1) to obtain compound 3a as a white solid (237 mg, 68.9\%). m.p: $135-138^{\circ} \mathrm{C}$. IR (film, $\left.\mathrm{cm}^{-1}\right) 3462$, $3171,2943,2869,1719,1640,1450,1385,1240,1132,1043,982,878 ;{ }^{1} \mathrm{H}$ NMR $\left(\mathrm{CDCl}_{3}, 400 \mathrm{MHz}\right) \delta:$ 0.76, 0.88, 0.93, 0.97 (each 3H, s, Me-24, -25, -26, -27), 1.74 (3H, s, Me-30), 2.00 (3H, s, 3-OAc), 3.00 (1H, m, H-19), 3.53 (1H, m, H-3), 3.68 (1H, d, $J=11.4 \mathrm{~Hz}, \mathrm{H}-23 \mathrm{a}), 3.83$ (1H, d, $J=11.4 \mathrm{~Hz}, \mathrm{H}-23 \mathrm{~b}), 4.62$ (1H, s, H-29a), 4.77 $(1 \mathrm{H}, \mathrm{s}, \mathrm{H}-29 \mathrm{~b})$; ESI-MS m/z: $537.3[\mathrm{M}+\mathrm{Na}]^{+}$; HRMS $(\mathrm{m} / z)(\mathrm{ESI})$ : calcd for $\mathrm{C}_{32} \mathrm{H}_{50} \mathrm{O}_{5} \mathrm{Na}[\mathrm{M}+\mathrm{Na}]^{+}:$537.3550; found: 537.3555 .

\subsubsection{3-Hydroxy-23-O-cyclohexyformyl-lup-20(29)-en-28-oic acid (3b)}

To a solution of 1 (100 mg, $0.21 \mathrm{mmol})$ in anhydrous pyridine $(3 \mathrm{~mL})$ was added DMAP (25 mg, $0.21 \mathrm{mmol})$, DCC (44 mg, $0.21 \mathrm{mmol})$ and cyclohexanecarboxylic acid $(27 \mathrm{mg}, 0.21 \mathrm{mmol})$. The mixture was stirred for $8 \mathrm{~h}$ at room temperature and then diluted with ethyl acetate $(50 \mathrm{~mL})$, acidified with $1 \mathrm{~N} \mathrm{HCl}(2.5 \mathrm{~mL})$. Then the solution was washed with water and brine, dried over anhydrous $\mathrm{Na}_{2} \mathrm{SO}_{4}$, and 
concentrated in vacuo. The residue was purified by chromatography on silica gel (petroleum ether-ethyl acetate 4:1 - 2:1) to afford compound $\mathbf{3 b}$ as a white solid (226 mg, 60.3\%). m.p: $131-133^{\circ} \mathrm{C}$. IR (film, $\mathrm{cm}^{-1}$ ) 3448, 3152, 2936, 2857, 1707, 1640, $1450,1399,1385,1247,1175,1133,1042,885 ;{ }^{1} \mathrm{H} \mathrm{NMR}\left(\mathrm{CDCl}_{3}, 300 \mathrm{MHz}\right) \delta: 0.67$ (3H, s), 0.79 (3H, s), $0.86(3 \mathrm{H}, \mathrm{s}), 0.89(3 \mathrm{H}, \mathrm{s}), 1.62$ (3H, s), 2.08-2.32 (3H, m), 2.95 (1H, m, H-19), $3.32(1 \mathrm{H}, \mathrm{t}, J=8.2 \mathrm{~Hz}, \mathrm{H}-3), 3.74,4.08$ (each 1H, d, $J=11.4 \mathrm{~Hz}$, $\mathrm{H}-23), 4.54,4.67$ (each 1H, s, H-29); ${ }^{13} \mathrm{C} \mathrm{NMR}\left(\mathrm{CDCl}_{3}, 75 \mathrm{MHz}\right) \delta: 11.7,14.5,16.0$, 16.5, 18.1, 19.4, 20.9, 24.7, 25.4, 25.8, 26.2, 29.1, 29.3, 29.7, 30.6, 32.2, 34.0, 37.0, 38.4, 38.7, 40.7, 42.3, 42.4, 43.4, 46.9, 48.1, 49.3, 50.8, 56.4, 66.2, 72.6, 109.6, 150.4, 176.2, 182.0; ESI-MS m/z: $605.4[\mathrm{M}+\mathrm{Na}]^{+}, 581.4[\mathrm{M}-\mathrm{H}]^{-}, 617.4[\mathrm{M}+\mathrm{Cl}]^{-} ; \mathrm{HRMS}$ $(m / z)(\mathrm{ESI})$ : calcd for $\mathrm{C}_{37} \mathrm{H}_{57} \mathrm{O}_{5}[\mathrm{M}-\mathrm{H}]^{-}: 581.4211$; found: 581.4218 .

\subsubsection{3-Hydroxy-23-O-(1-adamantaneformyl)-lup-20(29)-en-28-oic acid (3c)}

The titled compound $\mathbf{3 c}$ was obtained following the procedure described for $\mathbf{3 b}$. Yield: 58.1\%. White solid. m.p: $143-146^{\circ} \mathrm{C} .{ }^{1} \mathrm{H} \mathrm{NMR}\left(\mathrm{CDCl}_{3}, 300 \mathrm{MHz}\right) \delta: 0.85(3 \mathrm{H}$, s), $0.87(3 \mathrm{H}, \mathrm{s}), 0.97(6 \mathrm{H}, \mathrm{s}), 1.62(3 \mathrm{H}, \mathrm{s}), 1.93(4 \mathrm{H}, \mathrm{s}), 1.94(2 \mathrm{H}, \mathrm{s}), 2.17-2.30(2 \mathrm{H}$, m), 3.00 (1H, m, H-19), 3.39 (1H, d, $J=10.4 \mathrm{~Hz}, \mathrm{H}-23 \mathrm{a}), 3.62(1 \mathrm{H}, \mathrm{t}, J=7.9 \mathrm{~Hz}$, H-3), 3.69 (1H, d, $J=10.4 \mathrm{~Hz}, \mathrm{H}-23 \mathrm{~b}$ ), 4.62, 4.73 (each $1 \mathrm{H}, \mathrm{s}, \mathrm{H}-29) ;{ }^{13} \mathrm{C}$ NMR $\left(\mathrm{CDCl}_{3}, 75 \mathrm{MHz}\right) \delta: 11.3,14.7,16.0,16.5,18.4,19.4,20.9$, 25.5, 26.8, 27.6, 28.0, 29.7, 30.3, 31.7, 33.6, 34.1, 36.1, 36.3, 36.5, 37.1, 38.0, 38.2, 38.3, 38.5, 40.7, 41.9, 42.5, 46.5, 49.2, 49.8, 50.6, 58.0, 71.5, 109.9, 149.9, 171.9, 180.3; ESI-MS m/z: 669.4 $[\mathrm{M}+\mathrm{Cl}]^{-}$

\subsubsection{3-Hydroxy-23-O-benzoyl-lup-20(29)-en-28-oic acid (3d)}

The titled compound $\mathbf{3 d}$ was obtained following the procedure described for $\mathbf{3 b}$. Yield: $60.3 \%$. White solid. m.p: $130-132^{\circ} \mathrm{C}$. IR (film, $\mathrm{cm}^{-1}$ ) 3435, 3156, 2943, 2870, $1720,1700,1640,1601,1450,1399,1384,1271,1176,1111,1026,981,884,711 ;{ }^{1} \mathrm{H}$ NMR $\left(\mathrm{CDCl}_{3}, 300 \mathrm{MHz}\right) \delta: 0.83(3 \mathrm{H}, \mathrm{s}), 0.90(3 \mathrm{H}, \mathrm{s}), 0.96(6 \mathrm{H}, \mathrm{s}), 1.61(3 \mathrm{H}, \mathrm{s})$, 1.92-2.03 (2H, m), 2.16-2.33 (2H, m), $3.02(1 \mathrm{H}, \mathrm{m}, \mathrm{H}-19), 3.52(1 \mathrm{H}, \mathrm{t}, J=7.1 \mathrm{~Hz}$, H-3), 4.01, 4.50 (each 1H, d, $J=11.5$ Hz, H-23), 4.62, 4.75 (each 1H, s, H-29), 7.47 
$(2 \mathrm{H}, \mathrm{t}, J=7.4 \mathrm{~Hz}), 7.59(1 \mathrm{H}, \mathrm{t}, J=7.4 \mathrm{~Hz}), 8.06(2 \mathrm{H}, \mathrm{d}, J=7.2 \mathrm{~Hz}) ;{ }^{13} \mathrm{C} \mathrm{NMR}$ $\left(\mathrm{CDCl}_{3}, 75 \mathrm{MHz}\right) \delta: 11.9,14.5,16.0,16.6,18.2,19.4,20.9,24.7,25.5,26.3,30.6$, 32.2, 34.1, 37.1, 38.4, 38.7, 40.7, 42.4, 42.6, 46.9, 48.5, 49.3, 50.9, 56.4, 66.8, 72.4, 109.6, 128.5, 129.6, 130.2, 133.1, 150.4, 166.8, 182.1; ESI-MS m/z: $599.3[\mathrm{M}+\mathrm{Na}]^{+}$; HRMS (m/z) (ESI): calcd for $\mathrm{C}_{37} \mathrm{H}_{52} \mathrm{O}_{5} \mathrm{Na}[\mathrm{M}+\mathrm{Na}]^{+}:$599.3707; found: 599.3706.

\subsubsection{3-Hydroxy-23-O-(4-methoxybenzoyl)-lup-20(29)-en-28-oic acid (3e)}

The titled compound $\mathbf{3 e}$ was obtained following the procedure described for $\mathbf{3 b}$. Yield: $56.9 \%$. White solid. m.p: $121-124^{\circ} \mathrm{C} .{ }^{1} \mathrm{H} \mathrm{NMR}\left(\mathrm{CDCl}_{3}, 300 \mathrm{MHz}\right) \delta: 0.81(3 \mathrm{H}$, s), $0.88(3 \mathrm{H}, \mathrm{s}), 0.95(6 \mathrm{H}, \mathrm{s}), 1.68(3 \mathrm{H}, \mathrm{s}), 1.88-2.02(2 \mathrm{H}, \mathrm{m}), 2.13-2.32(2 \mathrm{H}, \mathrm{m}), 3.00$ (1H, m, H-19), 3.88 (3H, s), 3.93 (1H, m, H-3), 3.69 (1H, d, J = 11.6 Hz, H-23a), 4.49 (1H, d, $J=11.6 \mathrm{~Hz}, \mathrm{H}-23 \mathrm{~b}$ ), 4.60, 4.73 (each 1H, s, H-29), 6.94 (2H, d, J=8.8 Hz), $8.00(2 \mathrm{H}, \mathrm{d}, J=8.8 \mathrm{~Hz}) ;{ }^{13} \mathrm{C} \mathrm{NMR}\left(\mathrm{CDCl}_{3}, 75 \mathrm{MHz}\right) \delta: 11.9,14.5,16.0,16.6,18.2$, 19.4, 20.9, 24.8, 25.6, 26.2, 29.6, 30.6, 32.2, 33.8, 34.2, 37.1, 38.4, 38.7, 40.7, 42.4, 42.6, 46.9, 48.5, 49.2, 50.9, 55.5, 56.3, 66.5, 72.4, 109.7, 113.7, 122.2, 131.6, 150.4, 163.5, 166.4, 182.1; ESI-MS m/z: $607.4[\mathrm{M}+\mathrm{H}]^{+}$.

\subsubsection{3-Hydroxy-23-O-(2-nitrobenzoyl)-lup-20(29)-en-28-oic acid (3f)}

The titled compound $\mathbf{3 f}$ was obtained following the procedure described for $\mathbf{3 b}$. Yield: $62.5 \%$. White solid. m.p: 136-138 ${ }^{\circ} \mathrm{C}$. IR (film, $\mathrm{cm}^{-1}$ ) 3467, 3127, 2937, 2854, 1726, 1638, 1540, 1450, 1398, 1384, 1292, 1255, 1127, 1075, 967, 884, 791, 735, 699; ${ }^{1} \mathrm{H} \mathrm{NMR}\left(\mathrm{CDCl}_{3}, 300 \mathrm{MHz}\right) \delta: 0.71(3 \mathrm{H}, \mathrm{s}), 0.79(3 \mathrm{H}, \mathrm{s}), 0.86(3 \mathrm{H}, \mathrm{s}), 0.94(3 \mathrm{H}, \mathrm{s})$, 1.61 (3H, s), 2.07-2.24 (2H, m), 2.93 (1H, m, H-19), 3.43 (1H, m, H-3), 3.99 (1H, d, J $=11.4 \mathrm{~Hz}, \mathrm{H}-23 \mathrm{a}), 4.32$ (1H, d, $J=11.4 \mathrm{~Hz}, \mathrm{H}-23 \mathrm{~b}), 4.61,4.74$ (each 1H, s, H-29), 7.53-7.67 (2H, m), 7.72-7.85 (2H, m); ${ }^{13} \mathrm{C} \mathrm{NMR}\left(\mathrm{CDCl}_{3}, 75 \mathrm{MHz}\right) \delta: 11.7,14.6,16.0$, 16.6, 18.2 19.3, 20.9, 24.8, 25.6, 26.6, 29.7, 30.2, 30.6, 32.2, 33.7, 37.2, 38.4, 40.6, 42.4, 42.5, 46.9, 47.5, 49.2, 49.4, 50.3, 56.3, 68.4, 71.8, 109.5, 123.7, 126.9, 130.6, 132.1, 132.5, 150.5, 165.5, 181.6; ESI-MS m/z: $644.3[\mathrm{M}+\mathrm{Na}]^{+}$; HRMS ( $\left.m / z\right)(\mathrm{ESI})$ : calcd for $\mathrm{C}_{37} \mathrm{H}_{51} \mathrm{NO}_{7} \mathrm{Na}[\mathrm{M}+\mathrm{Na}]^{+}$: 644.3558; found: 644.3563 . 
The titled compound $\mathbf{3 g}$ was obtained following the procedure described for $\mathbf{3 b}$. Yield: $60.8 \%$. White solid. m.p: $137-139^{\circ} \mathrm{C} .{ }^{1} \mathrm{H} \mathrm{NMR}\left(\mathrm{CDCl}_{3}, 300 \mathrm{MHz}\right) \delta: 0.84(3 \mathrm{H}$, s), $0.91(3 \mathrm{H}, \mathrm{s}), 0.96(3 \mathrm{H}, \mathrm{s}), 0.97(3 \mathrm{H}, \mathrm{s}), 1.69(3 \mathrm{H}, \mathrm{s}), 2.15-2.33(2 \mathrm{H}, \mathrm{m}), 3.02(1 \mathrm{H}$, m, H-19), 3.50 (1H, m, H-3), 4.05 (1H, d, $J=11.4 \mathrm{~Hz}, \mathrm{H}-23 \mathrm{a}), 4.58$ (1H, d, $J=11.4$ Hz, H-23b), 4.61, 4.74 (each 1H, s, H-29), $7.70(1 \mathrm{H}, \mathrm{t}, J=8.0 \mathrm{~Hz}), 8.39$ (1H, d, $J=$ $7.8 \mathrm{~Hz}), 8.46(1 \mathrm{H}, \mathrm{d}, J=8.2 \mathrm{~Hz}), 8.86(1 \mathrm{H}, \mathrm{s}) ;{ }^{13} \mathrm{C} \mathrm{NMR}\left(\mathrm{CDCl}_{3}, 75 \mathrm{MHz}\right) \delta: 11.9$, $14.5,16.0,16.6,18.2,19.3,20.9,24.8,25.4,25.5,26.5,29.4,30.6,32.1,33.6,34.2$, 37.1, 38.4, 38.6, 40.7, 42.3, 42.6, 46.9, 48.6, 49.2, 49.4, 50.9, 56.3, 67.1, 72.2, 109.7, $124.4,127.5,129.8,132.0,135.3,148.3,150.4,164.6,181.9 ;$ ESI-MS m/z: 622.4 [M $+\mathrm{H}]^{+}$.

\subsubsection{3-Hydroxy-23-O-(4-nitrobenzoyl)-lup-20(29)-en-28-oic acid (3h)}

The titled compound $\mathbf{3 h}$ was obtained following the procedure described for $\mathbf{3 b}$. Yield: $48.9 \%$. White solid. m.p: $135-138^{\circ} \mathrm{C} .{ }^{1} \mathrm{H} \mathrm{NMR}\left(\mathrm{CDCl}_{3}, 300 \mathrm{MHz}\right) \delta: 0.84(3 \mathrm{H}$, s), $0.91(3 \mathrm{H}, \mathrm{s}), 0.95(3 \mathrm{H}, \mathrm{s}), 0.96(3 \mathrm{H}, \mathrm{s}), 1.70(3 \mathrm{H}, \mathrm{s}), 1.89-2.07(3 \mathrm{H}, \mathrm{m}), 2.16-2.32$ (2H, m), 3.03 (1H, m, H-19), 3.52 (1H, t $J=7.4 \mathrm{~Hz}, \mathrm{H}-3), 4.11,4.50$ (each 1H, d, $J=$ 11.4 Hz, H-23), 4.62, 4.74 (each 1H, s, H-29), 8.21 (2H, d, $J=8.8 \mathrm{~Hz}), 8.32$ (2H, d, $J$ $=8.8 \mathrm{~Hz}) ;{ }^{13} \mathrm{C} \mathrm{NMR}\left(\mathrm{CDCl}_{3}, 75 \mathrm{MHz}\right) \delta: 11.3,14.1,15.5,16.1,17.7,18.8,20.4,24.2$, 25.0, 26.1, 30.1, 31.6, 32.9, 33.7, 36.6, 37.9, 38.2, 40.2, 41.9, 42.1, 46.4, 48.2, 48.7, $50.5,55.8,66.9,71.8,109.2,123.2,130.1,135.2,149.8,150.1,164.3,181.3$; ESI-MS $m / z: 620.4[\mathrm{M}-\mathrm{H}]^{-}, 656.3[\mathrm{M}+\mathrm{Cl}]^{-}$.

\subsubsection{3-Hydroxy-23-O-(4-aminobenzoyl)-lup-20(29)-en-28-oic acid (3i)}

Add $10 \% \mathrm{Pd} / \mathrm{C}$ to a solution of $\mathbf{3 h}$ in tetramethylene oxide $(15 \mathrm{~mL})$ under $\mathrm{H}_{2}$ at atmospheric pressure. The mixture was stirred at room temperature for $0.5 \mathrm{~h}$. Then the solution was filtered and concentrated in vacuo. The residue was purified by chromatography on silica gel (petroleum ether-ethyl acetate 2:1) to afford $\mathbf{3 i}$ as a white solid. Yield: 86.5\%. m.p: 161-164 C. IR (film, cm ${ }^{-1}$ ) 3376, 3145, 2941, 2870, 1692, 1624, 1604, 1518, 1459, 1398, 1384, 1310, 1271, 1171, 1109, 1043, 980, 885,

770; ${ }^{1} \mathrm{H} \mathrm{NMR}\left(\mathrm{CDCl}_{3}, 300 \mathrm{MHz}\right) \delta: 0.80(3 \mathrm{H}, \mathrm{s}), 0.88(3 \mathrm{H}, \mathrm{s}), 0.94(3 \mathrm{H}, \mathrm{s}), 0.96(3 \mathrm{H}$, 
s), $1.68(3 \mathrm{H}, \mathrm{s}), 1.91-2.04(2 \mathrm{H}, \mathrm{m}), 2.13-2.32(2 \mathrm{H}, \mathrm{m}), 3.01(1 \mathrm{H}, \mathrm{m}, \mathrm{H}-19), 3.42(1 \mathrm{H}, \mathrm{t}$, $J=7.3 \mathrm{~Hz}, \mathrm{H}-3), 3.87,4.48$ (each 1H, d, $J=11.5 \mathrm{~Hz}, \mathrm{H}-23$ ), 4.61, 4.74 (each 1H, s, $\mathrm{H}-29), 6.65(2 \mathrm{H}, \mathrm{d}, J=8.3 \mathrm{~Hz}), 7.84(2 \mathrm{H}, \mathrm{d}, J=8.8 \mathrm{~Hz}) ;{ }^{13} \mathrm{C} \mathrm{NMR}\left(\mathrm{CDCl}_{3}, 75 \mathrm{MHz}\right)$ $\delta: 11.9,14.5,16.0,16.7,18.2,19.4,20.8,25.5,26.0,29.7,30.2,30.6,31.4,32.2,34.1$, 37.0, 38.4, 38.7, 40.7, 42.4, 42.6, 46.9, 48.5, 49.2, 50.8, 56.4, 66.3, 72.5, 109.7, 113.9, 119.4, 131.7, 150.4, 151.1, 167.1, 182.2; ESI-MS m/z: $592.4[\mathrm{M}+\mathrm{H}]^{+}, 614.4[\mathrm{M}+$ $\mathrm{Na}]^{+}$. HRMS $(\mathrm{m} / z)(\mathrm{ESI})$ : calcd for $\mathrm{C}_{37} \mathrm{H}_{54} \mathrm{NO}_{5}[\mathrm{M}+\mathrm{H}]^{+}:$592.3997; found: 592.3997 .

\subsubsection{3-Hydroxy-23-O-(3,5-dinitrobenzoyl)-lup-20(29)-en-28-oic acid (3j)}

The titled compound $\mathbf{3} \mathbf{j}$ was obtained following the procedure described for $\mathbf{3} \mathbf{b}$. Yield: $46.6 \%$. White solid. m.p: $145-147^{\circ} \mathrm{C} .{ }^{1} \mathrm{H} \mathrm{NMR}\left(\mathrm{CDCl}_{3}, 300 \mathrm{MHz}\right) \delta: 0.86(3 \mathrm{H}$, s), $0.93(3 \mathrm{H}, \mathrm{s}), 0.98(6 \mathrm{H}, \mathrm{s}), 1.70(3 \mathrm{H}, \mathrm{s}), 1.90-2.24(3 \mathrm{H}, \mathrm{m}), 2.17-2.31(2 \mathrm{H}, \mathrm{m}), 3.02$ (1H, m, H-19), 3.49 (1H, t, $J=7.2 \mathrm{~Hz}, \mathrm{H}-3), 4.12$ (1H, d, $J=11.4 \mathrm{~Hz}, \mathrm{H}-23 \mathrm{a}), 4.61$ (1H, s, H-29a), 4.66 (1H, d, J = 11.4 Hz, H-23b), 4.74 (1H, s, H-29b), 9.16 (2H, d, J = $2.0 \mathrm{~Hz}), 9.26(1 \mathrm{H}, \mathrm{s}) ;{ }^{13} \mathrm{C} \mathrm{NMR}\left(\mathrm{CDCl}_{3}, 75 \mathrm{MHz}\right) \delta: 11.9,14.5,16.0,16.6,18.3,19.3$, 20.9, 24.8, 25.5, 26.8, 30.6, 32.1, 33.6, 34.3, 37.0, 37.2, 38.4, 40.7, 42.3, 42.6, 46.9, 48.8, 49.2, 50.9, 56.3, 68.0, 72.1, 109.7, 122.4, 129.3, 134.0, 148.8, 150.4, 162.6, 181.7; ESI-MS m/z: 665.3 [M - H] $]^{-}, 701.3[\mathrm{M}+\mathrm{Cl}]^{-}$.

\subsubsection{3-Hydroxy-23-O-(4-fluorobenzoyl)-lup-20(29)-en-28-oic acid (3k)}

The titled compound $\mathbf{3 k}$ was obtained following the procedure described for $\mathbf{3 b}$. Yield: $66.0 \%$. White solid. m.p: $111-114^{\circ} \mathrm{C}$. IR (film, $\mathrm{cm}^{-1}$ ) 3448, 3134, 2942, 2870, $1718,1628,1604,1508,1451,1400,1384,1272,1152,1115,1044,853,767 ;{ }^{1} \mathrm{H}$ NMR $\left(\mathrm{CDCl}_{3}, 300 \mathrm{MHz}\right) \delta: 0.82(3 \mathrm{H}, \mathrm{s}), 0.89(3 \mathrm{H}, \mathrm{s}), 0.95(6 \mathrm{H}, \mathrm{s}), 1.68(3 \mathrm{H}, \mathrm{s})$, 1.93-2.12 (2H, m), 2.14-2.31 (2H, m), $3.03(1 \mathrm{H}, \mathrm{m}, \mathrm{H}-19), 3.47(1 \mathrm{H}, \mathrm{t}, J=7.4 \mathrm{~Hz}$, H-3), 3.99, 4.48 (each 1H, d, J = 11.5 Hz, H-23), 4.61, 4.74 (each 1H, s, H-29), 7.14 $(2 \mathrm{H}, \mathrm{m}), 8.06(2 \mathrm{H}, \mathrm{dd}, J=8.7,5.6 \mathrm{~Hz}) ;{ }^{13} \mathrm{C} \mathrm{NMR}\left(\mathrm{CDCl}_{3}, 75 \mathrm{MHz}\right) \delta: 11.8,14.5$, 16.0, 16.6, 18.2, 19.3, 20.9, 25.5, 26.4, 29.6, 30.6, 32.1, 34.2, 37.1, 38.4, 38.7, 40.7, 42.4, 42.6, 46.9, 48.6, 49.2, 51.0, 56.3, 66.8, 72.4, 109.7, 115.5, 115.8, 126.3, 132.0, 132.1, 150.3, 164.3, 165.8; ESI-MS m/z: 593.4 [M - H] ; HRMS (m/z) (ESI): calcd 
for $\mathrm{C}_{37} \mathrm{H}_{52} \mathrm{FO}_{5}[\mathrm{M}+\mathrm{H}]^{+}$: 595.3793; found: 595.3797.

\subsubsection{3-Hydroxy-23-O-(3-chlorobenzoyl)-lup-20(29)-en-28-oic acid (3l)}

The titled compound $\mathbf{3 l}$ was obtained following the procedure described for $\mathbf{3 b}$. Yield: $45.7 \%$. White solid. m.p: $140-142^{\circ} \mathrm{C} .{ }^{1} \mathrm{H} \mathrm{NMR}\left(\mathrm{CDCl}_{3}, 300 \mathrm{MHz}\right) \delta: 0.82(3 \mathrm{H}$, s), $0.89(3 \mathrm{H}, \mathrm{s}), 0.95(3 \mathrm{H}, \mathrm{s}), 0.98(3 \mathrm{H}, \mathrm{s}), 1.67(3 \mathrm{H}, \mathrm{s}), 2.1-2.28(2 \mathrm{H}, \mathrm{m}), 3.00(1 \mathrm{H}, \mathrm{m}$, H-19), 3.48 (1H, m, H-3), 4.03 (1H, d, $J=11.4 \mathrm{~Hz}, \mathrm{H}-23 \mathrm{a}), 4.50(1 \mathrm{H}, \mathrm{d}, J=11.4 \mathrm{~Hz}$, H-23b), 4.59, 4.72 (each 1H, s, H-29), $7.41(1 \mathrm{H}, \mathrm{d}, J=7.8 \mathrm{~Hz}), 7.55(1 \mathrm{H}, \mathrm{d}, J=8.7$ $\mathrm{Hz}), 7.91(1 \mathrm{H}, \mathrm{d}, J=7.8 \mathrm{~Hz}), 7.98(1 \mathrm{H}, \mathrm{s}) ;{ }^{13} \mathrm{C} \mathrm{NMR}\left(\mathrm{CDCl}_{3}, 75 \mathrm{MHz}\right) \delta: 11.9,14.5$, $16.0,16.6,18.2,19.3,20.9,24.8,25.4,25.6,26.5,29.7,30.6,32.1,33.7,34.2,37.1$, 38.4, 38.7, 40.6, 42.4, 42.6, 46.9, 48.5, 49.2, 49.4, 50.9, 56.4, 66.8, 72.2, 109.7, 127.7, 129.6, 129.8, 133.1, 150.4, 150.7, 172.5, 182.0; ESI-MS m/z: $609.3[\mathrm{M}-\mathrm{H}]^{-}$.

\subsubsection{3-Hydroxy-23-O-(2-trifluoromethylbenzoyl)-lup-20(29)-en-28-oic acid (3m)}

The titled compound $\mathbf{3 m}$ was obtained following the procedure described for $\mathbf{3 b}$. Yield: 56.6\%. White solid. m.p: $110-112^{\circ} \mathrm{C}$. IR (film, $\mathrm{cm}^{-1}$ ) 3466, 3129, 2939, 2856, 1718, 1637, 1450, 1399, 1384, 1314, 1261, 1169, 1139, 1052, 886, 768; ${ }^{1} \mathrm{H}$ NMR $\left(\mathrm{CDCl}_{3}, 300 \mathrm{MHz}\right) \delta: 0.82(3 \mathrm{H}, \mathrm{s}), 0.89(3 \mathrm{H}, \mathrm{s}), 0.96(6 \mathrm{H}, \mathrm{s}), 1.69(3 \mathrm{H}, \mathrm{s}), 2.18-2.31$

(2H, m), 3.01 (1H, m, H-19), 3.52 (1H, m, H-3), 4.14 (1H, d, $J=11.5$ Hz, H-23a), $4.43(1 \mathrm{H}, \mathrm{d}, J=11.5 \mathrm{~Hz}, \mathrm{H}-23 \mathrm{~b}), 4.61,4.74$ (each 1H, s, H-29), 7.63 (2H, m), 7.78 $(1 \mathrm{H}, \mathrm{m}), 7.83(1 \mathrm{H}, \mathrm{m}) ;{ }^{13} \mathrm{C} \mathrm{NMR}\left(\mathrm{CDCl}_{3}, 75 \mathrm{MHz}\right) \delta: 11.7,14.4,16.1,16.6,18.2$, $19.4,20.8,24.8,25.5,26.4,29.7,30.6,32.2,33.7,36.9,37.1,38.3,40.6,42.4,46.9$, $47.6,49.2,49.4,50.5,56.3,68.3,72.0,109.6,126.6,130.5,131.3,131.8,150.5,167.2$ 181.3; ESI-MS m/z: $667.3\left[\mathrm{M}+\mathrm{Na}^{+}\right.$; HRMS $(\mathrm{m} / z)(\mathrm{ESI})$ : calcd for $\mathrm{C}_{38} \mathrm{H}_{50} \mathrm{~F}_{3} \mathrm{O}_{5}[\mathrm{M}-$ $\mathrm{H]}]^{-}: 643.3616$; found: 643.3624 .

\subsubsection{3-Hydroxy-23-O-(4-trifluoromethylbenzoyl)-lup-20(29)-en-28-oic acid (3n)}

The titled compound $\mathbf{3 n}$ was obtained following the procedure described for $\mathbf{3 b}$. Yield: $63.5 \%$. White solid. m.p: $112-113{ }^{\circ} \mathrm{C} .{ }^{1} \mathrm{H} \mathrm{NMR}\left(\mathrm{CDCl}_{3}, 300 \mathrm{MHz}\right) \delta: 0.75(3 \mathrm{H}$, s), $0.82(3 \mathrm{H}, \mathrm{s}), 0.89(6 \mathrm{H}, \mathrm{s}), 1.61(3 \mathrm{H}, \mathrm{s}), 1.81-1.98(3 \mathrm{H}, \mathrm{m}), 2.07-2.24(2 \mathrm{H}, \mathrm{m}), 2.93$ (1H, m, H-19), $3.45(1 \mathrm{H}, \mathrm{t}, J=7.7 \mathrm{~Hz}, \mathrm{H}-3), 3.98,4.42($ each $1 \mathrm{H}, \mathrm{d}, J=11.5 \mathrm{~Hz}$, 
H-23), 4.53, 4.66 (each 1H, s, H-29), 7.65 (2H, d, $J=8.2 \mathrm{~Hz}$ ), 8.08 (2H, d, $J=8.2$ $\mathrm{Hz}) ;{ }^{13} \mathrm{C} \mathrm{NMR}\left(\mathrm{CDCl}_{3}, 75 \mathrm{MHz}\right) \delta: 11.3,14.0,15.5,16.1,17.7,18.8,20.4,24.1,25.0$, 26.0, , 30.1, 31.6, 32.8, 33.7, 36.6, 37.9, 38.2, 40.2, 41.9, 42.1, 46.4, 48.1, 48.8, 50.5, 55.9, 66.6, 71.8, 109.2, 125.0, 125.1, 129.4, 133.0, 149.8, 165.0, 181.4; ESI-MS m/z: $643.4[\mathrm{M}-\mathrm{H}]^{-}, 679.4[\mathrm{M}+\mathrm{Cl}]^{-}$.

\subsubsection{3-Hydroxy-23-O-(2,3,4,5-tetrafluorobenzoyl)-lup-20(29)-en-28-oic acid (3o)}

The titled compound $\mathbf{3 o}$ was obtained following the procedure described for $\mathbf{3 b}$. Yield: $60.3 \%$. White solid. m.p: $134-137^{\circ} \mathrm{C} .{ }^{1} \mathrm{H} \mathrm{NMR}\left(\mathrm{CDCl}_{3}, 300 \mathrm{MHz}\right) \delta: 0.74(3 \mathrm{H}$, s), $0.81(3 \mathrm{H}, \mathrm{s}), 0.88(3 \mathrm{H}, \mathrm{s}), 0.90(3 \mathrm{H}, \mathrm{s}), 1.62(3 \mathrm{H}, \mathrm{s}), 1.83-1.97(3 \mathrm{H}, \mathrm{m}), 2.08-2.24$ (2H, m), 2.94 (1H, m, H-19), 3.44 (1H, t $J=7.7 \mathrm{~Hz}, \mathrm{H}-3), 3.98,4.42$ (each 1H, d, $J=$

$11.4 \mathrm{~Hz}, \mathrm{H}-23), 4.54,4.67$ (each 1H, s, H-29), $7.56(1 \mathrm{H}, \mathrm{dd}, J=14.1,7.9 \mathrm{~Hz}) ;{ }^{13} \mathrm{C}$ NMR $\left(\mathrm{CDCl}_{3}, 75 \mathrm{MHz}\right) \delta: 11.1,13.8,15.5,16.0,17.6,18.8,20.4,24.3,25.0,26.2$, 29.1, 30.1, 31.6, 33.4, 36.5, 37.9, 38.0, 40.2, 41.7, 41.9, 46.4, 47.4, 48.7, 50.3, 55.8, 67.6, 71.7, 109.1, 112.7, 113.0, 114.5, 149.9, 161.8, 181.2; ESI-MS m/z: $647.3[\mathrm{M}-$ $\mathrm{H}]^{-}$.

\subsubsection{3-Hydroxy-23-O-(4-benzylsulfonyl)-lup-20(29)-en-28-oic acid (3p)}

The titled compound $\mathbf{3 p}$ was obtained following the procedure described for $\mathbf{3 b}$. Yield: 50.9\%. White solid. m.p: $165-167^{\circ} \mathrm{C}$. IR (film, $\mathrm{cm}^{-1}$ ) 3415, 3128, 2945, 2870, 1686, 1638, 1598, 1500, 1460, 1400, 1385, 1356, 1264, 1189, 1167, 1111, 1045, 960, 834; ${ }^{1} \mathrm{H}$ NMR $\left(\mathrm{CDCl}_{3}, 300 \mathrm{MHz}\right) \delta: 0.65(3 \mathrm{H}, \mathrm{s}), 0.81(3 \mathrm{H}, \mathrm{s}), 0.89(3 \mathrm{H}, \mathrm{s}), 0.97(3 \mathrm{H}$, s), $1.70(3 \mathrm{H}, \mathrm{s}), 1.97-2.03(2 \mathrm{H}, \mathrm{m}), 2.17(1 \mathrm{H}, \mathrm{m}), 2.28(1 \mathrm{H}, \mathrm{m}), 3.00(1 \mathrm{H}, \mathrm{m}, \mathrm{H}-19)$, 3.59 (1H, m, H-3), 3.69 (1H, d, $J=9.7 \mathrm{~Hz}, \mathrm{H}-23 \mathrm{a}), 3.88(3 \mathrm{H}, \mathrm{s}), 3.96(1 \mathrm{H}, \mathrm{d}, J=9.8$ Hz, H-23b), 4.61, 4.74 (each 1H, s, H-29), 7.01 (2H, d, $J=8.9 \mathrm{~Hz}), 7.85$ (2H, d, $J=$ $8.9 \mathrm{~Hz}) ;{ }^{13} \mathrm{C} \mathrm{NMR}\left(\mathrm{CDCl}_{3}, 75 \mathrm{MHz}\right) \delta: 11.5,14.8,15.9,16.5,17.8,19.3,20.8,25.4$, 26.6, 29.6, 30.6, 31.1, 33.7, 37.0, 38.2, 38.4, 40.6, 42.4, 42.4, 46.9, 47.0, 49.2, 50.3, 55.7, 56.4, 71.1, 71.5, 109.7, 114.4, 127.4, 130.0, 150.3, 163.7, 182.2; ESI-MS m/z: $665.3[\mathrm{M}+\mathrm{Na}]^{+}$; HRMS (m/z) (ESI): calcd for $\mathrm{C}_{37} \mathrm{H}_{53} \mathrm{O}_{7} \mathrm{~S}[\mathrm{M}-\mathrm{H}]^{-}: 641.3517$; found: 641.3526 . 


\subsubsection{3-Hydroxy-23-O-(3-picolinoyl)-lup-20(29)-en-28-oic acid (3q)}

The titled compound $\mathbf{3 q}$ was obtained following the procedure described for $\mathbf{3 b}$. Yield: $42.1 \%$. White solid. m.p: $154-157^{\circ} \mathrm{C}$. IR (film, $\mathrm{cm}^{-1}$ ) 3468, 3127, 2945, 2857, 1719, 1638, 1590, 1400, 1385, 1289, 1129, 1042, 880, 740; ${ }^{1} \mathrm{H}$ NMR $\left(\mathrm{CDCl}_{3}, 300\right.$ MHz) $\delta: 0.75(3 \mathrm{H}, \mathrm{s}), 0.82(3 \mathrm{H}, \mathrm{s}), 0.86(3 \mathrm{H}, \mathrm{s}), 0.88(3 \mathrm{H}, \mathrm{s}), 1.61(3 \mathrm{H}, \mathrm{s}), 1.82-1.98$ (3H, m), 2.10-2.22 (2H, m), $2.94(1 \mathrm{H}, \mathrm{m}, \mathrm{H}-19), 3.45$ (1H, t, $J=7.3 \mathrm{~Hz}, \mathrm{H}-3), 4.02$, $4.40($ each $1 \mathrm{H}, \mathrm{d}, J=11.4 \mathrm{~Hz}, \mathrm{H}-23), 4.53,4.66$ (each 1H, s, H-29), $7.36(1 \mathrm{H}, \mathrm{dd}, J=$ 7.7, $5.1 \mathrm{~Hz}), 8.25(1 \mathrm{H}, \mathrm{d}, J=7.9 \mathrm{~Hz}), 8.75(1 \mathrm{H}, \mathrm{d}, J=3.7 \mathrm{~Hz}), 9.16(1 \mathrm{H}, \mathrm{s}) ;{ }^{13} \mathrm{C} \mathrm{NMR}$ $\left(\mathrm{CDCl}_{3}, 75 \mathrm{MHz}\right) \delta: 11.8,14.6,16.0,16.6,18.2,19.3,20.9,25.5,26.6,30.3,30.6$, $32.2,34.2,37.1,38.4,38.6,40.7,42.4,42.6,46.9,48.6,49.2,50.9,56.3,67.0,72.2$, 109.6, 123.5, 126.3, 137.3, 150.4, 150.5, 153.3, 165.2, 181.1; ESI-MS m/z: 578.3 [M $+\mathrm{H}]^{+} ; \mathrm{HRMS}(\mathrm{m} / \mathrm{z})(\mathrm{ESI})$ : calcd for $\mathrm{C}_{36} \mathrm{H}_{50} \mathrm{NO}_{5}[\mathrm{M}-\mathrm{H}]^{-}:$576.3694; found: 576.3702 .

\subsubsection{3-Hydroxy-23-O-(indole-2-formyl)-lup-20(29)-en-28-oic acid (3r)}

The titled compound $\mathbf{3 r}$ was obtained following the procedure described for $\mathbf{3} \mathbf{b}$. Yield: $39.6 \%$. White solid. m.p: $166-168^{\circ} \mathrm{C} .{ }^{1} \mathrm{H} \mathrm{NMR}\left(\mathrm{CDCl}_{3}, 300 \mathrm{MHz}\right) \delta: 0.79(3 \mathrm{H}$, s), $0.90(6 \mathrm{H}, \mathrm{s}), 1.01(3 \mathrm{H}, \mathrm{s}), 1.63(3 \mathrm{H}, \mathrm{s}), 2.08-2.27(2 \mathrm{H}, \mathrm{m}), 2.97(1 \mathrm{H}, \mathrm{m}, \mathrm{H}-19)$, $3.38(1 \mathrm{H}, \mathrm{m}, \mathrm{H}-3), 4.07,4.17$ (each 1H, d, $J=11.5 \mathrm{~Hz}, \mathrm{H}-23), 4.55,4.68$ (each 1H, s, H-29), $7.01(1 \mathrm{H}, \mathrm{s}), 7.10(1 \mathrm{H}, \mathrm{m}), 7.51(2 \mathrm{H}, \mathrm{m})$; ESI-MS m/z: $614.4[\mathrm{M}-\mathrm{H}]^{-}$.

\subsubsection{3-Hydroxy-23-O-(indole-4-formyl)-lup-20(29)-en-28-oic acid (3s)}

The titled compound $\mathbf{3 s}$ was obtained following the procedure described for $\mathbf{3 b}$. Yield: $46.7 \%$. White solid. m.p: $161-163{ }^{\circ} \mathrm{C} .{ }^{1} \mathrm{H}$ NMR (DMSO- $\left.d_{6}, 300 \mathrm{MHz}\right) \delta: 0.69$ $(3 \mathrm{H}, \mathrm{s}), 0.83(3 \mathrm{H}, \mathrm{s}), 0.87(3 \mathrm{H}, \mathrm{s}), 0.89(3 \mathrm{H}, \mathrm{s}), 1.64(3 \mathrm{H}, \mathrm{s}), 2.06(1 \mathrm{H}, \mathrm{m}), 2.22(1 \mathrm{H}$, m), 2.95 (1H, m, H-19), 3.47 (1H, m, H-3), 3.93, 4.17 (each 1H, d, J=11.0 Hz, H-23), 4.56, 4.69 (each 1H, s, H-29), $6.56(1 \mathrm{H}, \mathrm{s}), 7.49(2 \mathrm{H}, \mathrm{d}, J=2.9 \mathrm{~Hz}), 7.74(2 \mathrm{H}, \mathrm{d}, J=$ $8.4 \mathrm{~Hz}), 8.26(1 \mathrm{H}, \mathrm{s}), 11.5(1 \mathrm{H}, \mathrm{s}), 12.1(1 \mathrm{H}, \mathrm{brs}) ;{ }^{13} \mathrm{C} \mathrm{NMR}\left(\mathrm{CDCl}_{3}, 75 \mathrm{MHz}\right) \delta: 12.7$, $14.5,16.2,16.7,18.2,19.4,20.9,25.5,27.1,30.5,30.9,32.1,34.1,37.0,38.0,38.8$, 40.7, 42.1, 42.4, 47.1, 48.3, 49.0, 50.9, 55.8, 65.8, 70.8, 102.9, 110.1, 111.8, 121.3, 122.2, 122.9, 127.7, 138.9, 150.7, 167.0, 177.7; ESI-MS m/z: $614.4[\mathrm{M}-\mathrm{H}]^{-}$ 


\subsubsection{Benzyl 3, 23-dihydroxy-lup-20(29)-en-28-oate (4)}

To a solution of $1(5.00 \mathrm{~g}, 10.5 \mathrm{mmol})$ in DMF (60 mL) was successively added $\mathrm{K}_{2} \mathrm{CO}_{3}(5.00 \mathrm{~g}, 36 \mathrm{mmol})$ and benzyl bromide $(1.5 \mathrm{~mL}, 12.5 \mathrm{mmol})$. The mixture was stirred for $12 \mathrm{~h}$ at room temperature and then poured into water $(15 \mathrm{~mL})$ and extracted with ethyl acetate $(80 \mathrm{~mL} \times 3)$. The organic layer was washed with water and brine, dried over anhydrous sodium sulfate, and concentrated in vacuo. The residue was purified by chromatography on silica gel (petroleum ether-ethyl acetate 2:1) to afford compound 4 as a white solid $(5.4 \mathrm{~g}, 90.3 \%) .{ }^{1} \mathrm{H} \mathrm{NMR}\left(\mathrm{CDCl}_{3}, 300 \mathrm{MHz}\right) \delta: 0.75(3 \mathrm{H}$, s), $0.84(6 \mathrm{H}, \mathrm{s}), 0.93(3 \mathrm{H}, \mathrm{s}), 1.67(3 \mathrm{H}, \mathrm{s}), 2.11-2.22(1 \mathrm{H}, \mathrm{m}), 2.23-2.29(1 \mathrm{H}, \mathrm{m}), 3.01$ (1H, m, H-19), 3.37 (1H, d, $J=9.9 \mathrm{~Hz}, \mathrm{H}-23 \mathrm{a}), 3.59$ (1H, m, H-3), 3.67 (1H, d, $J=$ $9.8 \mathrm{~Hz}, \mathrm{H}-23 \mathrm{~b}$ ), 4.59, 4.72 (each 1H, s, H-29), 5.05-5.17 (2H, m, $-\mathrm{CH}_{2} \mathrm{Ar}$ ), 7.23-7.42 $(5 \mathrm{H}, \mathrm{m}, \mathrm{H}-\mathrm{Ar}) ;{ }^{13} \mathrm{C} \mathrm{NMR}\left(\mathrm{CDCl}_{3}, 75 \mathrm{MHz}\right) \delta: 11.3,14.7,15.8,16.5,18.4,19.4,20.9$, 25.5, 26.8, 29.6, 30.6, 32.1, 34.0, 36.9, 37.0, 38.1, 38.4, 40.6, 41.8, 42.4, 46.9, 49.4, $49.9,50.5,56.5,65.7,71.8,76.6,109.6,128.1,128.2,128.5,136.4,150.5,175.8$; ESI-MS $m / z: 563.3[\mathrm{M}+\mathrm{H}]^{+}, 585.3[\mathrm{M}+\mathrm{Na}]^{+}, 601.4[\mathrm{M}+\mathrm{K}]^{+}$.

\subsubsection{3-Hydroxy-23-O-[N,N-bis(2-chloroethyl)aminobenzoyl]-lup-20(29)-en-28-oic $\operatorname{acid}(6 a)$}

To a solution of 4 (200 mg, $0.35 \mathrm{mmol})$ in anhydrous $\mathrm{CH}_{2} \mathrm{Cl}_{2}(10 \mathrm{~mL})$ was added DMAP $\quad(42 \quad \mathrm{mg}, \quad 0.35 \mathrm{mmol}), \quad$ DCC $\quad\left(\begin{array}{lllll}73 & \mathrm{mg}, & 0.35 & \mathrm{mmol}\end{array}\right)$ and 4-(bis(2-chloroethyl)amino)benzoic acid (92 mg, $0.35 \mathrm{mmol})$. The mixture was stirred for $12 \mathrm{~h}$ at room temperature and then diluted with ethyl acetate $(50 \mathrm{~mL})$. Then the solution was washed with $1 \mathrm{~N} \mathrm{HCl}(4 \mathrm{~mL})$, water and brine, dried over anhydrous sodium sulfate, and concentrated in vacuo. The residue was purified by chromatography on silica gel (petroleum ether-ethyl acetate 8:1 - 5:1) to afford benzyl product. Added $10 \% \mathrm{Pd} / \mathrm{C}$ to a solution of benzyl product in tetramethylene oxide (15 $\mathrm{mL})$ under $\mathrm{H}_{2}$ at atmospheric pressure. The mixture was stirred at room temperature for $0.5 \mathrm{~h}$. Then the solution was filtered and concentrated in vacuo. The residue was purified by chromatography on silica gel (petroleum ether-ethyl acetate 2:1) to afford compound 6a as a white solid (138 mg, 55.3\%). m.p: $135-138^{\circ} \mathrm{C} .{ }^{1} \mathrm{H}$ NMR $\left(\mathrm{CDCl}_{3}\right.$, 
$300 \mathrm{MHz}) \delta: 0.77(3 \mathrm{H}, \mathrm{s}), 0.80(3 \mathrm{H}, \mathrm{s}), 0.85(3 \mathrm{H}, \mathrm{s}), 0.92(3 \mathrm{H}, \mathrm{s}), 1.67$ (3H, s, Me-30), $2.18(1 \mathrm{H}, \mathrm{m}), 2.27(1 \mathrm{H}, \mathrm{m}), 3.00(1 \mathrm{H}, \mathrm{m}, \mathrm{H}-19), 3.41$ (1H, m, H-3), 3.62-3.68 (4H, m), 3.75-3.83 (4H, m), 3.89 (1H, d, $J=11.4 \mathrm{~Hz}, \mathrm{H}-23 \mathrm{a}), 4.47$ (1H, d, $J=11.4 \mathrm{~Hz}, \mathrm{H}-23 \mathrm{~b})$, 4.59 (1H, s, H-29a), 4.72 (1H, s, H-29b), $6.67(2 \mathrm{H}, \mathrm{d}, J=9.1 \mathrm{~Hz}), 7.92(2 \mathrm{H}, \mathrm{d}, J=9.1$ $\mathrm{Hz}) ;{ }^{13} \mathrm{C} \mathrm{NMR}\left(\mathrm{CDCl}_{3}, 75 \mathrm{MHz}\right) \delta: 11.9,14.6,15.8,16.7,18.2,19.4,20.9,25.5,26.1$, 29.5, 30.6, 32.1, 34.1, 36.9, 37.1, 38.2, 38.7, 40.1, 40.7, 42.4, 42.7, 46.9, 48.6, 49.4, 50.9, 53.3, 56.5, 65.7, 72.4, 109.6, 110.9, 128.5, 131.8, 149.8, 166.8, 181.2; ESI-MS $m / z: 714.4[\mathrm{M}-\mathrm{H}]^{-}$.

\subsubsection{3-Hydroxy-23-O-( $\beta$-aminopropionyl)-lup-20(29)-en-28-oic acid (6d)}

To a solution of $N$-tert-butoxycarbonyl- $\beta$-alanine $(66 \mathrm{mg}, 0.35 \mathrm{mmol})$ in anhydrous $\mathrm{CH}_{2} \mathrm{Cl}_{2}(10 \mathrm{~mL})$ was added DMAP (42 mg, $\left.0.35 \mathrm{mmol}\right), \mathrm{DCC}$ (73 mg, $0.35 \mathrm{mmol}$ ). The mixture was stirred for $1 \mathrm{~h}$ at room temperature, then added 4 (197 $\mathrm{mg}, 0.35 \mathrm{mmol}$ ), and the mixture was stirred for $12 \mathrm{~h}$ at room temperature and then diluted with ethyl acetate $(50 \mathrm{~mL})$. Then the solution was washed with $1 \mathrm{~N} \mathrm{HCl}(4$ $\mathrm{mL}$ ), water and brine, dried over anhydrous sodium sulfate, and concentrated in vacuo. The residue was purified by chromatography on silica gel (petroleum ether-ethyl acetate $8: 1-5: 1)$ to afford benzyl product $\mathbf{5 b}$. Added $10 \% \mathrm{Pd} / \mathrm{C}$ to a solution of benzyl product in tetramethylene oxide $(15 \mathrm{~mL})$ under $\mathrm{H}_{2}$ at atmospheric pressure. The mixture was stirred at room temperature for $0.5 \mathrm{~h}$. Then the solution was filtered and concentrated in vacuo. The residue was purified by chromatography on silica gel (petroleum ether-ethyl acetate 2:1) to afford intermediate product $6 \mathbf{b}$. $6 \mathbf{b}$ was dissolved in anhydrous dichloromethane $(10 \mathrm{~mL})$, and trifluoroacetic acid $(1.5 \mathrm{~mL})$ was added under ice bath. The mixture was stirred for $3 \mathrm{~h}$ at room temperature and then concentrated and chromatographed over silica gel (dichloromethane-methanol $30: 1-10: 1)$ to give $6 \mathbf{d}(42 \mathrm{mg}, 26.9 \%)$ as a white solid. m.p: $153-155^{\circ} \mathrm{C}$. IR (film, $\left.\mathrm{cm}^{-1}\right)$ 3448, 3139, 2946, 2874, 1759, 1685, 1637, 1450, 1400, 1385, 1190, 1132, 1043 , 966, 800, 723; ${ }^{1} \mathrm{H}$ NMR $\left(\mathrm{CDCl}_{3}, 300 \mathrm{MHz}\right) \delta$ : 0.87 (6H, s), 0.94 (3H, s), 0.97 (3H, s), 1.69 (3H, s, Me-30), 2.20-2.28 (2H, m), 2.67-2.69 (2H, m), 2.96-3.00 (1H, m, H-19), 3.17-3.19 (2H, m), 3.42 (1H, d, $J=10.3 \mathrm{~Hz}, \mathrm{H}-23 \mathrm{a}), 3.60-3.65$ (m, 1H, H-3), 3.72 
$(1 \mathrm{H}, \mathrm{d}, J=10.4 \mathrm{~Hz}, \mathrm{H}-23 \mathrm{~b}), 4.61(1 \mathrm{H}, \mathrm{s}, \mathrm{H}-29 \mathrm{a}), 4.74(1 \mathrm{H}, \mathrm{s}, \mathrm{H}-29 \mathrm{~b}) ;{ }^{13} \mathrm{C} \mathrm{NMR}$ (DMSO- $d_{6}, 75$ MHz) $\delta: 12.87,14.84,16.19,16.76,17.93,19.40,20.97,25.62,27.22$, $29.68,30.58,32.21,33.97,36.21,36.88,37.22,37.85,38.05,38.55,40.65,42.38$, 42.49, 47.11, 48.04, 49.01, 50.44, 55.88, 64.93, 70.81, 110.11, 150.74, 173.29, 177.71;ESI-MS m/z: $544.4[\mathrm{M}+\mathrm{H}]^{+}$; HRMS (m/z) $(\mathrm{ESI})$ : calcd for $\mathrm{C}_{33} \mathrm{H}_{54} \mathrm{NO}_{5}[\mathrm{M}+$ $\mathrm{H}]^{+}:$544.3997; found: 544.3998.

\subsubsection{3-Hydroxy-23-O-(4-piperidinylformyl)-lup-20(29)-en-28-oic acid (6e)}

The titled compound $\mathbf{6 e}$ was obtained following the procedure described for $\mathbf{6 d}$. Yield: $31.5 \%$. White solid. m.p: $158-159^{\circ} \mathrm{C}$. IR (film, $\mathrm{cm}^{-1}$ ) 3431, 3134, 2946, 2869, $1728,1637,1560,1451,1399,1385,1190,1107,1041,883 ;{ }^{1} \mathrm{H} \mathrm{NMR}\left(\mathrm{CDCl}_{3}, 300\right.$ MHz) $\delta: 0.75(3 \mathrm{H}, \mathrm{s}), 0.88(3 \mathrm{H}, \mathrm{s}), 0.91(3 \mathrm{H}, \mathrm{s}), 0.95(3 \mathrm{H}, \mathrm{s}), 1.66(3 \mathrm{H}, \mathrm{s}), 2.45-2.52$ (1H, m), 2.65-2.73 (2H, m), 3.10-3.14 (2H, m), 3.34-3.42 (1H, m, H-3), 3.85 (1H, d, J $=11.5 \mathrm{~Hz}, \mathrm{H}-23 \mathrm{a}), 3.94(1 \mathrm{H}, \mathrm{s}), 4.17(1 \mathrm{H}, \mathrm{d}, J=11.4 \mathrm{~Hz}, \mathrm{H}-23 \mathrm{~b}), 4.63,4.76$ (each $1 \mathrm{H}$, s, H-29); ${ }^{13} \mathrm{C}$ NMR (DMSO- $\left.d_{6}, 75 \mathrm{MHz}\right) \delta$ : 12.90, 14.86, 16.29, 16.79, 17.96, 19.46, $21.01,25.62,27.59,29.75,30.74,32.61,34.01,36.89,37.14,37.98,38.43,38.63$, $40.66,40.96,42.42,42.50,43.93,47.13,48.57,49.14,50.48,56.08,64.85,70.72$, 109.88, 151.12, 176.43, 178.39; ESI-MS m/z: 584.4[M + H] $]^{+}$; HRMS $(m / z)(E S I):$ calcd for $\mathrm{C}_{36} \mathrm{H}_{58} \mathrm{NO}_{5}[\mathrm{M}+\mathrm{H}]^{+}:$584.4310; found: 584.4308 .

\subsection{Biology}

\subsubsection{Cell lines and cultures}

A2780 (human ovarian cancer cell), A375 (human melanoma), MCF-7 (human breast cancer) and HepG2 (human liver cancer) were originally obtained from American Type Culture Collection (ATCC), USA and stock was maintained in laboratory; B16 (mice melanoma) and L-O2 (human normal liver) were obtained from Type Culture Collection of Chinese Academy of Sciences Committee. All cell lines were cultured in RPMI 1640 (Gibco) containing 10\% fetal bovine serum (Gibco) and $1 \%$ penicillin streptomycin (Gibco) at $37{ }^{\circ} \mathrm{C}$ in the presence of $5 \% \mathrm{CO}_{2}$. 
The antiproliferative activity of the compounds was determined using MTT assay. Cells were seeded in 96-well micro culture plates incubated for $24 \mathrm{~h}$ at $37{ }^{\circ} \mathrm{C}$ in $\mathrm{CO}_{2}$ incubator. All of the reported betulinic derivatives were dissolved in DMSO while the positive control doxorubicin was dissolved in PBS. These tested compounds at different concentrations were added into wells and cells were treated at $37{ }^{\circ} \mathrm{C}$ for $72 \mathrm{~h}$. Then MTT (5 mg/mL, in PBS) was added into each well and cultured for another $4 \mathrm{~h}$. The optical density was detected in a microplate reader at $570 \mathrm{~nm}$. IC 50 values were calculated according to the dose dependent curves.

\subsubsection{Flow cytometry}

\subsubsection{Reactive oxygen species (ROS) analysis}

B16 cancer cells were plated into 6-well culture plates and treated without or with compound $6 \mathbf{e}$ at indicated concentration for $72 \mathrm{~h}$. DCFH-DA was diluted to $10 \mu \mathrm{mol} / \mathrm{L}$ with cell medium and incubation with cells for $20 \mathrm{~min}$ at $37^{\circ} \mathrm{C}$. Finally, cells were washed with serum-free medium for three times. Then, the intracellular ROS levels were detected with flow cytometer $(E x=488 \mathrm{~nm} ; \mathrm{Em}=530 \mathrm{~nm})$.

\subsubsection{Mitochondrial membrane potential (MMP) assay}

B16 cells were cultured overnight and incubated in triplicate with the compound 6e $(0,0.75,1.5,3.0 \mu \mathrm{M})$ for $48 \mathrm{~h}$. The cells were stained with the lipophilic cationic dye JC-1, according to the manufacturer's instruction (Keygen, KGA601). The percentage of cells with healthy or collapsed mitochondrial membrane potentials was monitored by flow cytometry analysis.

\subsubsection{Western Blot analysis}

B16 cells were incubated in the presence of $6 \mathbf{e}$ and collected after $72 \mathrm{~h}$. Cells were centrifuged and washed two times with ice cold phosphate buffered saline. The pellet was then resuspended in lysis buffer. After the cells were lysed on ice for 30 min, lysates were centrifuged at $13,000 \mathrm{~g}$ at $4{ }^{\circ} \mathrm{C}$ for $10 \mathrm{~min}$. The protein concentration in the supernatant was measured with the Braford protein content 
detection kit. Equal amounts of protein $(70 \mu \mathrm{g})$ were electrophoresed using sodium dodecyl sulfate-polyacrylamide gel electrophoresis (SDS-PAGE) (8-15\% acrylamide gels) and transferred onto PVDF Hybond-P membrane. Membranes were blocked for $1 \mathrm{~h}$ in $5 \%$ fat-free milk at room temperature. Membranes were then incubated with primary antibodies against caspase-3, Bax, Bcl-2, MEK, p-MEK, ERK, p-ERK, Akt, p-Akt with gentle rotation overnight at $4{ }^{\circ} \mathrm{C}$. Membranes were next incubated with fluorescent secondary antibodies for $60 \mathrm{~min}$ and were determined by densimetric scanning.

\subsubsection{Anti-tumor assay in vivo}

A total of $1 \times 10^{7}$ B16 cells were subcutaneously inoculated into the right flank of ICR mice with body weight of $18-22 \mathrm{~g}$ according to protocols of tumor transplant research. After incubation for 1 day, mice were weighted and at random divided into four groups with eight animals per group. The groups treated with 6e were administered intraperitoneously $15 \mathrm{mg} / \mathrm{kg}, 30 \mathrm{mg} / \mathrm{kg}$ in a vehicle of $10 \% \mathrm{DMSO} / 2 \%$ Tween $80 / 88 \%$ saline, respectively. The positive control group was treated with 5-FU $(30 \mathrm{mg} / \mathrm{kg}$ ) by intraperitoneous injection. The negative control group received a vehicle of $10 \%$ DMSO/2\% Tween $80 / 88 \%$ saline through intraperitoneous injection. Treatments of 6e was conducted at a frequency of one dose per day for a total 21 consecutive days, while the positive group was treated with 5-FU one dose per two days. Body weights and tumor volumes were measured every 2 days. After the treatments, all the mice were sacrificed and weighed. The following formula was used to determine tumor volumes: tumor volume $=\mathrm{L} \times \mathrm{W}^{2} / 2$, where $\mathrm{L}$ is the length and $\mathrm{W}$ is the width. The ratio of inhibition of tumor $(\%)=(1-$ average tumor weight of treated group/average tumor weight of control group) $\times 100 \%$. All procedures were performed following institutional approval in accordance with the NIH Guide for the Care and Use of Laboratory Animals.

\section{Acknowledgements}

This study was supported from the National Natural Science Foundation of China 
(No. 81673306) for financial support, and "Double First-Class" University project CPU2018GY04, CPU2018GY35, China Pharmaceutical University.

\section{References}

[1] D.J. Newman, G.M. Cragg, Natural products as sources of new drugs from 1981 to 2014, J. Nat. Prod. 79 (2016) 629-661.

[2] P. Dzubak, M. Hajduch, D. Vydra, A. Hustova, M. Kvasnica, D. Biedermann,

L. Markova, M. Urban, J. Sarek, Pharmacological activities of natural triterpenoids and their therapeutic implications, Nat. Prod. Rep. 23 (2006) 394-411.

[3] R. A. Cichewicz, S. A. Kouzi, Chemistry, biological activity, and chemotherapeutic potential of betulinic acid for the prevention and treatment of cancer and HIV infection. Med. Res. Rev. 24 (2004) 90-114.

[4] W.K. Liu, J.C. Ho, F.W. Cheung, B.P. Liu, W.C. Ye, C.T. Che, Apoptotic activity of betulinic acid derivatives on murine melanoma B16 cell line, Eur. J. Pharmacol. 498 (2004) 71-78

[5] Y. Zheng, F. Zhou, X. Wu, X. Wen, Y. Li, B. Yan, J. Zhang, G. Hao, W. Ye, G. Wang, 23-Hydroxybetulinic acid from Pulsatilla chinensis (Bunge) Regel synergizes the antitumor activities of doxorubicin in vitro and in vivo, J. Ethnopharmacol. 128 (2010) 615-622.

[6] D.M. Zhang, C. Shu, J.J. Chen, K. Sodani, J. Wang, J. Bhatnagar, P. Lan, Z.X. Ruan, Z.J. Xiao, S.V. Ambudkar, W.M. Chen, Z.S. Chen, W.C. Ye, BBA, a derivative of 23-hydroxybetulinic acid, potently reverses $\mathrm{ABCB} 1$-mediated drug resistance in vitro and in vivo, Mol. Pharm. 9 (2012) 3147-3159.

[7] J.J. Chen, A. Patel, K. Sodani, Z.J. Xiao, A.K. Tiwari, D.M. Zhang, Y.J. Li, D.H. Yang, W.C. Ye, S.D. Chen, Z.S. Chen, BBA, a synthetic derivative of 23hydroxybutulinic acid, reverses multidrug resistance by inhibiting the efflux activity of MRP7 (ABCC10), PLoS One 8 (2013) -74573.

[8] Z.N. Ji, W.C. Ye, G.G. Liu, W.L. Hsiao, 23-Hydroxybetulinic acid-mediated apoptosis is accompanied by decreases in bcl-2 expression and telomerase activity in HL-60 Cells, Life Sci. 72 (2002) 1-9. 
[9] H. Yao, G.X. Wei, Y.P. Liu, H.Q. Yao, Z.Y. Zhu, W.C. Ye, X.M. Wu, J.Y Xu, S.T. $\mathrm{Xu}$, Synthesis, biological evaluation of fluorescent 23-hydroxybetulinic acid probes, and their cellular localization studies, ACS Med. Chem. Lett. 9 (2018) 1030-1034

[10] Y. Bi, J.Y. Xu, F. Sun, X.M. Wu, W.C. Ye, Y.J. Sun, W.W. Huang, Synthesis and biological activity of 23-hydroxybetulinic acid C-28 ester derivatives as antitumor agent candidates, Molecules. 17 (2012) 8832-8841.

[11] Y. Bi, J.Y. Xu, X.M. Wu, W.C. Ye, S.T. Yuan, L.Y. Zhang, Synthesis and cytotoxic activity of 17-carboxylic acid modified 23-hydroxybetulinic acid ester derivatives, Bioorg. Med. Chem. Lett. 17 (2007) 1475-1478.

[12] H.Y. Zhang, F.Z. Li, P.Q. Zhu, J. Liu, H.Q. Yao, J.Y. Jiang, W.C. Ye, X.M. Wu, J.Y. Xu, Synthesis and biological evaluation of oxygen-containing heterocyclic ring-fused 23-hydroxybetulinic acid derivatives as antitumor agents, Chem Biol Drug Des. 86 (2015) 424-431.

[13] H.Y. Zhang, P.Q. Zhu, J. Liu, Y. Lin, H.Q. Yao, J.Y. Jiang, W.C. Ye, X.M. Wu, J.Y. Xu, Synthesis, in vitro and in vivo antitumor activity of pyrazole-fused 23-hydroxybetulinic acid derivatives, Bioorg. Med. Chem. Lett. 25 (2015) 728-732.

[14] H.Y. Zhang, Y.W. Wang, P.Q. Zhu, J. Liu, S.T. Xu, H.Q. Yao, J.Y. Jiang, W.C. Ye, X.M. Wu, J.Y. Xu, Design, synthesis and antitumor activity of triterpenoid pyrazine derivatives from 23-hydroxybetulinic acid, Eur. J. Med. Chem. 97 (2015) 235-244. [15] P. Lan, J. Wang, D.M. Zhang, C. Shu, H.H. Cao, P.H. Sun, X.M. Wu, W.C. Ye, W.M. Chen, Synthesis and antiproliferative evaluation of 23-hydroxybetulinic acid derivatives, Eur. J. Med. Chem. 46 (2011) 2490-2502.

[16]P. T. Schumacker, Reactive oxygen species in cancer: a dance with the devil, Cancer cell, 27 (2015) 156-157.

[17] J.D. Ly, D.R. Grubb, A. Lawen, The mitochondrial membrane potential (Delta psi m) in apoptosis; an update, Apoptosis. 8 (2003) 115-128.

[18] I. YaJima, M.Y. Kumasaka, N.D. Thang, Y. Goto, K. Takeda, O. Yamanoshita, M. Iida, N. Ohgami, H. Tamura, Y. Kawamoto, RAS/RAF/MEK/ERK and $\mathrm{PI} 3 \mathrm{~K} / \mathrm{PTEN} / \mathrm{AKT}$ signaling in malignant melanoma progression and therapy, Dermat Res and Pract, 2012 (2013) 354191. 